OPEN ACCESS

Edited by:

Uta Passow,

University of California, Santa Barbara,

USA

Reviewed by:

Lucas Stal,

Royal Netherlands Institute for Sea Research (NWO), Netherlands

Hélène Montanié,

University of La Rochelle, France

*Correspondence: Julio Bohórquez julio.bohorquez@uca.es

Specialty section This article was submitted to Aquatic Microbiology,

a section of the journal

Frontiers in Microbiology

Received: 05 October 2016 Accepted: 06 February 2017 Published: 27 February 2017

Citation:

Bohórquez J, McGenity TJ, Papaspyrou S, García-Robledo E, Corzo A and Underwood GJC (2017)

Different Types of Diatom-Derived Extracellular Polymeric Substances Drive Changes in Heterotrophic Bacterial Communities from Intertidal Sediments. Front. Microbiol. 8:245. doi: 10.3389/fmicb.2017.00245

\section{Different Types of Diatom-Derived Extracellular Polymeric Substances Drive Changes in Heterotrophic Bacterial Communities from Intertidal Sediments}

\author{
Julio Bohórquez ${ }^{1,2 *}$, Terry J. McGenity ${ }^{2}$, Sokratis Papaspyrou ${ }^{3}$, Emilio García-Robledo ${ }^{1,4}$, \\ Alfonso Corzo ${ }^{1}$ and Graham J. C. Underwood ${ }^{2}$ \\ ${ }^{1}$ Department of Biology, Faculty of Marine and Environmental Science, University of Cádiz, Puerto Real, Spain, ${ }^{2}$ School of \\ Biological Sciences, University of Essex, Colchester, UK, ${ }^{3}$ Departamento de Biomedicina, Biotecnología y Salud Publica, \\ Universidad de Cádiz, Puerto Real, Spain, ${ }^{4}$ Microbiology Section, Department of Biosciences, University of Aarhus, Aarhus, \\ Denmark
}

Intertidal areas support extensive diatom-rich biofilms. Such microphytobenthic (MPB) diatoms exude large quantities of extracellular polymeric substances (EPS) comprising polysaccharides, glycoproteins and other biopolymers, which represent a substantial carbon pool. However, degradation rates of different EPS components, and how they shape heterotrophic communities in sediments, are not well understood. An aerobic mudflat-sediment slurry experiment was performed in the dark with two different EPS carbon sources from a diatom-dominated biofilm: colloidal EPS (cEPS) and the more complex hot-bicarbonate-extracted EPS. Degradation rate constants determined over 9 days for three sediment fractions [dissolved organic carbon (DOC), total carbohydrates (TCHO), and (cEPS)] were generally higher in the colloidal-EPS slurries (0.105-0.123 $\mathrm{d}^{-1}$ ) compared with the hot-bicarbonate-extracted-EPS slurries $\left(0.060-0.096 \mathrm{~d}^{-1}\right)$. Addition of hot-bicarbonate-EPS resulted in large increases in dissolved nitrogen and phosphorous by the end of the experiment, indicating that the more complex EPS is an important source of regenerated inorganic nutrients. Microbial biomass increased 4-6-fold over 9 days, and pyrosequencing of bacterial 16S rRNA genes revealed that the addition of both types of EPS greatly altered the bacterial community composition (from 0 to 9 days) compared to a control with no added EPS. Bacteroidetes (especially Tenacibaculum) and Verrucomicrobia increased significantly in relative abundance in both the hot-bicarbonate-EPS and colloidal-EPS treatments. These differential effects of EPS fractions on carbon-loss rates, nutrient regeneration and microbial community assembly improve our understanding of coastal-sediment carbon cycling and demonstrate the importance of diverse microbiota in processing this abundant pool of organic carbon.

Keywords: EPS, microphytobenthos, intertidal sediment, nutrient regeneration, G-model, degradation rate, microbial community, pyrosequencing 


\section{INTRODUCTION}

Microphytobenthic communities inhabiting intertidal sediments, such as salt marshes and mudflats, exhibit high rates of primary production (Underwood et al., 2005) and are able to influence carbon and nitrogen fluxes in shallow-water systems (Perkins et al., 2001; Thornton et al., 2002; McKew et al., 2013). Benthic diatoms are the major autotrophic microphytobenthic group in fine (cohesive) intertidal sediments, and can contribute up to $50 \%$ of the autochthonous carbon fixation in some ecosystems (Underwood et al., 2005). This productivity contributes to the ecosystem service and carbon and nitrogen cycling provision of coastal habitats (Beaumont et al., 2014; Luisetti et al., 2014). Benthic diatoms inhabit the first few millimeters of the sediment and exude extracellular polymeric substances (EPS), which play important ecological roles including motility of the pennate diatoms (Underwood and Paterson, 2003; Hanlon et al., 2006) and protection of cells from desiccation and salinity stress (Steele et al., 2014). In addition, EPS are used by bacteria, meio- and macrofauna as carbon and energy sources (Middelburg et al., 2000; Haynes et al., 2007; Bellinger et al., 2009) and contribute to sediment stability (Underwood and Paterson, 2003; Ubertini et al., 2015).

Diatom EPS include a wide range of different organic macromolecules, primarily polysaccharides (up to 90\%: Underwood et al., 2010), but also glycoproteins and lesser amounts of lipids, nucleic acids and proteins (Hoagland et al., 1993; Underwood and Paterson, 2003; Hofmann et al., 2009). EPS is operationally described as material that precipitates in polar solvents (Decho, 1990), and can be separated by extraction procedures, for example. colloidal EPS (EPS coll $_{1}$ ), water-soluble polymeric material isolated from colloidal aqueous extracts, and hot-bicarbonate extracted EPS (EPS $\mathrm{HB}_{\mathrm{B}}$ ), higher molecular weight (HMW) and more insoluble compounds such as tightly bound and capsular EPS, solubilized using hot bicarbonate extraction protocols (Bellinger et al., 2005; Aslam et al., 2016). These labile and bound EPS fractions differ in biochemical composition, and in the seasonal changes of their chemical composition (Pierre et al., 2014; Passarelli et al., 2015).

Carbohydrate content varies between 40 and $90 \%$ of the EPScarbon within diatom-rich biofilms (Underwood and Smith, 1998; Underwood and Paterson, 2003). The response of the heterotrophic bacterial community to this carbon source depends on its biochemistry, with bacteria having to deploy extracellular enzymes to transform the more complex EPS molecules into smaller monomers and oligosaccharides prior to uptake (Hofmann et al., 2009; Thornton et al., 2010; Arnosti, 2011). Previous slurry experiments have shown rapid utilization, within hours, of low-molecular-weight compounds, followed by a slower rate of degradation of more complex EPS by particular groups of bacteria (Haynes et al., 2007; Hofmann et al., 2009). The diversity of EPS composition results in a great variety of bacteria being involved in their degradation (Bacteroidetes, together with Alpha-, Beta- and Gammaproteobacteria, including Acinetobacter) (Elifantz et al., 2005; Haynes et al., 2007; McKew et al., 2013; Taylor et al., 2013; Passarelli et al., 2015). Coupling between diatom-derived EPS and bacterial community composition has been demonstrated (Taylor et al., 2013; Miyatake et al., 2014); nevertheless, still little is known about the loss processes affecting EPS budgets in intertidal sediments, and in particular on the differential degradation of the range of EPS produced within biofilms (McKew et al., 2013).

In order to better understand the effect of EPS composition on its turnover, we performed a microcosm experiment using slurries from intertidal diatom-dominated sediment enriched with two different carbon sources: colloidal EPS (EPS coll $\left._{\text {ill }}\right)$, and more tightly-bound, extracellular components of the capsular EPS associated with the surface of the diatom frustules (EPS $\mathrm{HB}_{\mathrm{BB}}$ ), extracted from natural MPB biofilms. Our hypothesis was that due to the differences in structural complexity, the degradation rate of EPS coll would be faster than for $\mathrm{EPS}_{\mathrm{HB}}$, and that the dominant groups of bacteria would change in relation to their preference and ability to respond to the different EPS components. Since EPS, in addition to carbohydrates, contain a certain amount of proteins, glycoproteins and phospholipids (Hoagland et al., 1993; Underwood and Paterson, 2003; Hofmann et al., 2009), we hypothesized that EPS degradation might be a (previously unknown) source of regenerated nutrients ( $\mathrm{N}$ and $\mathrm{P}$ ) in marine sediments.

In order to test these hypotheses, we compared changes in EPS-enriched slurries of: (1) concentrations of Dissolved Organic Carbon (DOC), which contains mainly carbohydrate and also amino acids and other low-molecular-weight organic carbon compounds; (2) concentrations of Total Carbohydrates (TCHO), which includes all dissolved and particulate carbohydrate and also structural polysaccharides; (3) concentrations of cEPS, (4) changes in the concentrations of inorganic nutrients, and (5) biomass and bacterial community assemblages based on DNA assays.

\section{MATERIALS AND METHODS Sampling Site and Extraction of Carbohydrates Fractions}

Surface sediment (top $2 \mathrm{~mm}$ depth) was collected in October 2012 from a tidal mudflat near Alresford creek (Colne Estuary) $\left(51^{\circ} 50^{\prime} 14.9^{\prime \prime} \mathrm{N}, 0^{\circ} 59^{\prime} 35.2^{\prime \prime} \mathrm{E}\right)$ (UK), where abundant diatomdominated biofilms were present. Sediment was frozen at $-20^{\circ} \mathrm{C}$ for $12 \mathrm{~h}$ and freeze-dried overnight. Two different operational EPS fractions (Underwood and Paterson, 2003) were extracted (multiple extractions of $5 \mathrm{~g}$ of sediment) from the freeze-dried sediments, following a sequential extraction procedure. First, the colloidal EPS fraction $\left(\mathrm{EPS}_{\text {coll }}\right)$ of watersoluble carbohydrate fractions was obtained (Decho, 1990). Then, after a hot-water extraction (to remove intracellular carbohydrates), a hot-bicarbonate (HB) solubilization step was performed (addition of $0.5 \mathrm{M} \mathrm{NaHCO}_{3}$ solution at $95^{\circ} \mathrm{C}$ for $1 \mathrm{~h}$ ) to obtain a fraction containing gelatinous extracellular polysaccharides termed $\mathrm{EPS}_{\mathrm{HB}}$ (Bellinger et al., 2005).

The supernatant containing either EPS $\mathrm{Eoll}_{\text {ll }}$ or $\mathrm{EPS}_{\mathrm{HB}}$ was precipitated in ethanol ( $70 \%$ final concentration) overnight at $4^{\circ} \mathrm{C}$, then centrifuged at room temperature $(3,000 \times \mathrm{g}, 15 \mathrm{~min})$, the supernatant discarded and the resultant EPS pellets from 
the parallel extractions pooled and resuspended in $400 \mathrm{~mL}$ of deionized water. The EPS ${ }_{\text {coll }}$ and EPS $\mathrm{HB}_{\mathrm{HB}}$ extracts were dialyzed at room temperature overnight through an $8 \mathrm{kDa}$ dialysis tubing against ultrapure water $(18.2 \mathrm{M} \Omega \mathrm{cm}$, Milli-Q) with moderate stirring, to reach a final salinity $<1 \%$. Subsamples of $\mathrm{EPS}_{\text {coll }}$ and $\mathrm{EPS}_{\mathrm{HB}}$ extracts were measured spectrophotometrically (485 $\mathrm{nm}$ ) after a phenol-sulfuric acid assay reaction (Dubois et al., 1956) as described by Hanlon et al. (2006). Carbohydrate concentration was quantified $\left(\mu \mathrm{g} \mathrm{mL}^{-1}\right)$ as glucose equivalents (later transformed to $\mu \mathrm{mol} \mathrm{C} \mathrm{L}^{-1}$ ) using a $D$-glucose standard curve. The final EPS coll $_{\text {and }}$ PPS $_{\mathrm{HB}}$ extracts $\left(215 \mathrm{mg} \mathrm{C} \mathrm{L}^{-1}\right)$ were kept in the dark at $4^{\circ} \mathrm{C}$, and subsamples used for amendment of sediment slurry experiments.

\section{Experimental Microcosms}

Fresh sediment (top $2 \mathrm{~mm}$ ) from the same location as that used for the EPS extraction was sampled on 3rd December 2012 and used to make the sediment slurries within 1 day. Five different slurry treatments were prepared each in triplicate $100 \mathrm{~mL}$ conical

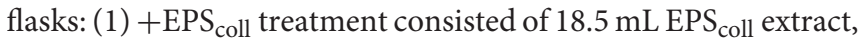
$61.5 \mathrm{~mL}$ artificial sea water (salinity 35) and $200 \mathrm{mg}$ wet weight estuarine sediment (containing $\sim 120 \mu \mathrm{g}$ DOC, McKew et al., 2013). As a result, the slurry had a total volume of $80 \mathrm{~mL}$ with a salinity of 27 and a dissolved carbon concentration of $51.5 \mathrm{mg} \mathrm{C} \mathrm{L}^{-1}$; (2) the $+\mathrm{EPS}_{\mathrm{HB}}$ treatment was established using an identical setup but with the addition of Hot-Bicarbonate-

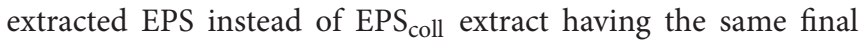
carbon concentration; (3) NoSed-EPS coll $_{\text {and (4) NoSed-EPS }}$ HB controls had the same amount of the relevant EPS extract and artificial sea water as before but with no sediment added to check for abiotic loss; and (5) NoAdd-EPS control contained sediment and artificial sea water but no additional carbon source to check for changes in bacterial composition that are not a consequence of growing on the added EPS.

The flasks were placed on a rocking platform (100 r. p. m.) at $16^{\circ} \mathrm{C}$ in the dark to avoid an increase of carbon content as result of primary production. Samples were taken every 3 days for a total of 9 days.

\section{Organic Carbon and Carbohydrates}

At each sampling time, subsamples of slurries $(8 \mathrm{~mL})$ were taken from each flask to measure organic carbon and carbohydrates in three inter-related fractions. Aliquots of $2.5 \mathrm{~mL}$ were filtered through pre-combusted GF/F filters, then diluted 10-fold with Milli-Q water to measure DOC on a Shimadzu TOC-VCSH Analyzer. An aliquot of slurry $(4.5 \mathrm{~mL})$ was centrifuged $(3,000$ $\times \mathrm{g}, 15 \mathrm{~min}$ ), after mixing by vortexing to remove the sediment particles and obtain a supernatant containing the colloidal material. The resultant supernatant was used to obtain the cEPS by precipitation in ethanol (70\% final concentration). The remaining non-filtered $1 \mathrm{~mL}$ aliquot was used to measure TCHO. This fraction includes dissolved and colloidal carbohydrates as well as HW and HB fractions. Both cEPS and TCHO were quantified using the phenol-sulfuric acid assay as mentioned previously.

To quantitatively assess the degradability of the different organic fractions in the treatments, time course changes of the three carbon fractions, DOC, TCHO, and cEPS, were modeled in two ways. First, in order to facilitate comparison with other studies where only lineal degradation rates were provided, a linear degradation model according to Equation (1):

$$
G_{t}=G_{o}-b \cdot t
$$

Secondly, the so-called one-G model of organic matter degradation (Berner, 1964) was implemented using the following exponential equation:

$$
G_{t}=G_{o}^{-k t}
$$

where, $G_{t}$ is the concentration of the organic fraction at time $t, G_{o}$ is the initial concentration, $b$ is the lineal degradation rate $(\mu \mathrm{mol}$ $\left.\mathrm{C}_{\text {org }} \mathrm{L}^{-1} \mathrm{~d}^{-1}\right)$ and $k$ is the degradation constant in $\mathrm{d}^{-1}$ units.

\section{Inorganic Nutrients}

A portion of slurry ( $8 \mathrm{ml}$ for days 0 and 9 , and $4 \mathrm{ml}$ for days 3 and 6) was transferred to a $15 \mathrm{ml}$ Falcon tube, centrifuged at 3,000 $\times$ $\mathrm{g}$ for $10 \mathrm{~min}$, the supernatant was filtered using pre-combusted $\mathrm{GF} / \mathrm{F}$ filters, and frozen immediately at $-20^{\circ} \mathrm{C}$, and later used to measure dissolved inorganic nutrients. Nitrate $\left(\mathrm{NO}_{3}^{-}\right)$, nitrite $\left(\mathrm{NO}_{2}^{-}\right)$and ammonium $\left(\mathrm{NH}_{4}^{+}\right)$, phosphate $\left(\mathrm{PO}_{4}^{3-}\right)$ and silicate $\left(\mathrm{SiO}_{4}^{4-}\right)$ were measured on a Seal Analytical AA3 HR Nutrient Autoanalyzer following the protocols described by Grasshoff et al. (1983).

To quantitatively assess the net rate of inorganic nutrient regeneration, time course changes in nutrients were fitted to a linear equation, where the slope represents the net regeneration rate. With some nutrients and in some treatments the use of a positive exponential model improved the correlation coefficients but we used a linear model in all cases to facilitate comparison.

\section{Bacterial Community Analysis DNA Extraction and Microbial Biomass Estimation}

The pellet obtained after centrifuging the slurry for nutrients analysis was retained and frozen at $-20^{\circ} \mathrm{C}$ until DNA extraction. DNA was extracted from sediment pellets using a beadbeating phenol-chloroform-isoamyl alcohol method as described previously (McKew et al., 2011).

Small aliquots $(1 \mu \mathrm{L})$ of extracted total DNA were diluted and used as a proxy to estimate the total biomass of the microbial community with a NanoDrop ${ }^{\circledR}$ 3,300 fluorospectrometer, with replicates $(n=3)$ stained using Quant-iT ${ }^{\mathrm{TM}}$ PicoGreen ${ }^{\circledR}$ dsDNA reagent and measured on the basis of absorbance at $260 \mathrm{~nm}$. The DNA extraction and subsequent quantification method applied here is used comparatively as a general biomass growth indicator, as it does not distinguish between the major groups (Bacteria, Archaea, Eukarya) or between intracellular DNA (from live and dead intact cells) and extracellular DNA (actively released or originating from lysed cells) (Torti et al., 2015).

\section{PCR Amplification of Bacterial 16S rRNA Genes}

PCR amplifications were carried out using bacterial primers 341GC-F (CGCCCGCCGCGCGCGGCGGGCGGGGCG 
GGGGCACGGGGGGCCTACGGGAGGCAGCAG) and 534R (ATTACCGCGGCTGCTGG) (Muyzer et al., 1993) for denaturing gradient gel electrophoresis (DGGE) analysis. All PCR amplifications were performed using a GeneAmp PCR system 9700 thermocycler (Applied Biosystems) as described by Folwell et al. (2016). Thermocycling consisted of $95^{\circ} \mathrm{C}$ for $5 \mathrm{~min}$ followed by 32 cycles of $95^{\circ} \mathrm{C}$ for $5 \mathrm{~s}, 55^{\circ} \mathrm{C}$ for $30 \mathrm{~s}, 72^{\circ} \mathrm{C}$ for $30 \mathrm{~s}$, with a final elongation of $72^{\circ} \mathrm{C}$ for $7 \mathrm{~min}$.

\section{DGGE}

DGGE analysis of bacterial 16S rRNA gene amplicons was performed using the Bio-Rad D Code system as described by Muyzer et al. (1993), running for $16 \mathrm{~h}$ on a gradient of $40-60 \%$, and stained with silver nitrate (Acuña Alvarez et al., 2009).

\section{Pyrosequencing}

The composition of the bacterial communities was assessed from 16S rRNA genes libraries constructed from the DNA extracts of selected samples $\left(+\mathrm{EPS}_{\text {coll }}\right.$ treatment replicates at day 0 as representative of the starting community, and replicates of $+\mathrm{EPS}_{\mathrm{coll}},+\mathrm{EPS}_{\mathrm{HB}}$, and NoAdd-EPS treatments at day 9; Supplementary Table S1) using ROCHE 454 pyrosequencing technology at the NERC Molecular Genetic Facility at the University of Liverpool as described previously (McKew et al., 2011). The analytical procedure described by Folwell et al. (2016) was used. In brief, any sequences $<150$ bp in read length, containing errors or with low-quality scores, were removed from analysis. The remaining reads were clustered into operational taxonomic units (OTUs) at 95\% similarity level and assigned to a taxonomic group using RDP classifier algorithm (Wang et al., 2007).

\section{Statistical Analysis}

All analyses were performed with three replicates for each sampling time. Differences in carbohydrate fractions and inorganic nutrients over time and with respect to treatments were tested by two-way repeated measures analysis of variance (factor time and factor treatment) (ANOVA) follow by Student Newman-Kewls multiple comparison tests when significant differences were found. Differences between degradation rates for DOC, TCHO, and cEPS calculated with both the linear degradation model and the one-G model (with data previously linearized by a $L n$ transform) were tested by comparison of slope by analysis of covariance (ANCOVA). Analyses were performed using the software PAST v 3.10 (Hammer et al., 2001).

Concentration of DNA was $L n$ transformed and fitted to a linear model where slopes represented the net growth. Differences between treatments $+\mathrm{EPS}_{\text {coll }}$ and $+\mathrm{EPS}_{\mathrm{HB}}$ were tested by comparison of slopes by ANCOVA.

Changes in the community composition with treatment and over time were analyzed by permutational analysis of variance (PERMANOVA) (Anderson, 2001) on a Bray Curtis similarity resemblance matrix on data normalized by the total number of good reads in each sample. A total of 10,000 unrestricted permutations was set in all tests. When the number of permutations was small $(<100)$, $p$-values were obtained through Monte Carlo random draw from the asymptotic permutation

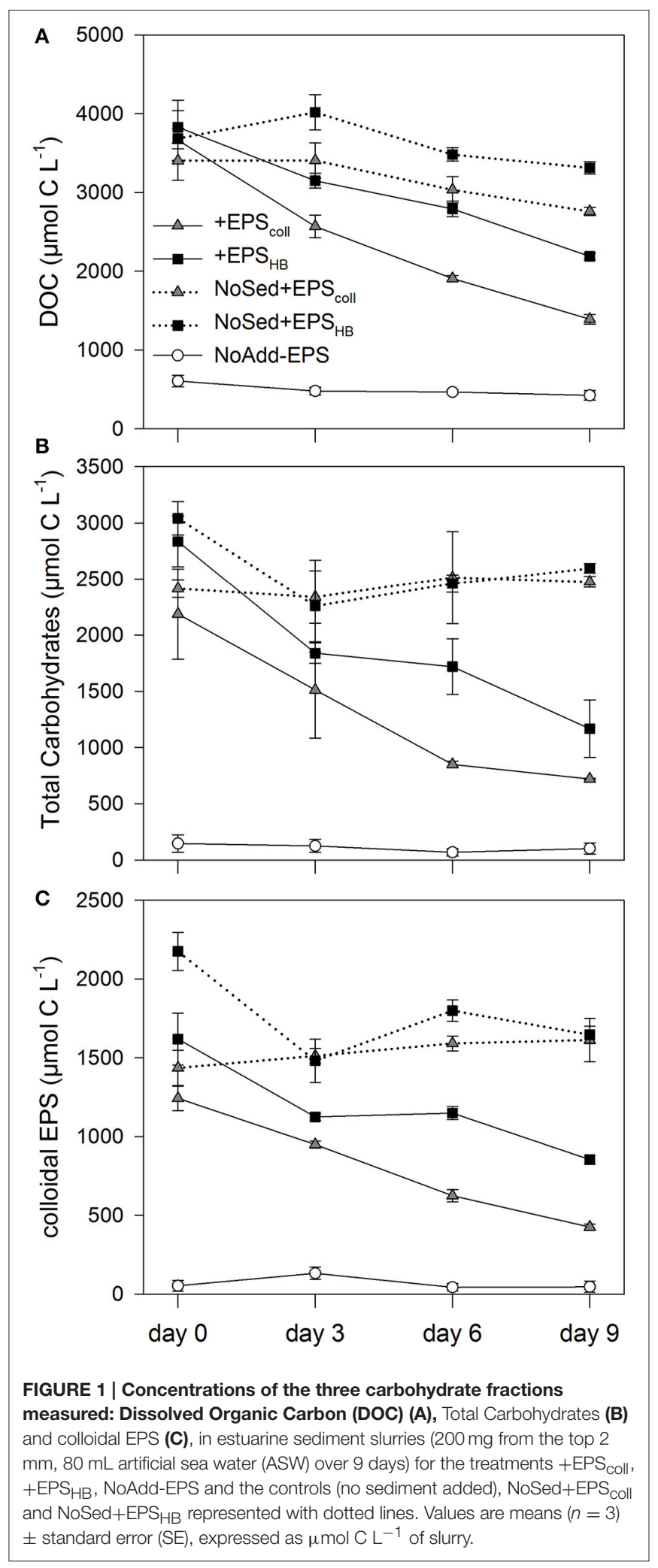

distribution (Anderson and Robinson, 2003). Community data patterns were then represented non-metric Multi-Dimensional Scaling (MDS) using a Bray-Curtis similarity index. Pearson 
correlation biplots of $\log (x+1)$ transformed variables were drawn onto the MDS axes to examine their relationship with observed community patterns. All statistical analyses were run using the programs PRIMER 6.0 and PERMANOVA+ (PRIMER-e).

To test significant differences in taxonomic profiles of bacterial community at day 9 from the $+\mathrm{EPS}_{\text {coll }},+\mathrm{EPS}_{\mathrm{HB}}$, and NoAdd-EPS treatments, both at Class and at OTU level, we used Whelch's $t$-test implementation of STAMP v2 1.3 package (Parks and Beiko, 2010; Parks et al., 2014) with default parameters except that parameters for filtering out were: $p>0.05$; difference between proportions $<0.2$ or differences between ratios $<1.5$.

\section{Sequence Accession}

Raw pyrosequences of amplified bacterial 16S rRNA genes from all the samples can be extracted from the European Nucleotide Archive (ENA) under accession number PRJEB15429. Supplementary Table S1 provides the information required to identify the relationship between sample and sequences.

\section{RESULTS}

\section{Changes in Organic Carbon and Carbohydrate Fractions}

The addition of EPS resulted in significantly higher DOC concentrations (between 3,600 and $3,800 \mu \mathrm{mol} \mathrm{C} \mathrm{L} \mathrm{L}^{-1}$ on day 0 , corresponding to 1.44 and $1.52 \mathrm{mmol} \mathrm{C} \mathrm{g}^{-1}$ Wet Weight (WW) sediment, respectively) in all four EPS-addition treatments compared with the NoAdd-EPS control (DOC concentration 608 $\pm 74 \mu \mathrm{mol} \mathrm{C} \mathrm{L} \mathrm{L}^{-1}$ or $0.24 \mathrm{mmol} \mathrm{C} \mathrm{g}{ }^{-1} \mathrm{WW}$ sediment on day 0) (Figure 1A; Student-Newman-Keuls (SNK test), $p<0.05$ ). Similarly, the TCHO concentration and cEPS concentration at day $0\left(0.8-1.1 \mathrm{mmol} \mathrm{C} \mathrm{g}{ }^{-1} \mathrm{WW}\right.$ sediment and $0.5-0.6 \mathrm{mmol}$ C $\mathrm{g}^{-1}$ WW sediment, respectively) were 15-19-fold and 2030-fold higher, respectively, in EPS-supplemented microcosms compared with the NoAdd-EPS control (Figures 1B,C). The concentrations of DOC, TCHO and cEPS decreased significantly throughout the 9-day experiment in the treatments that had both added EPS and sediment inocula $\left(+\mathrm{EPS}_{\mathrm{coll}},+\mathrm{EPS}_{\mathrm{HB}}\right)$ (Figures 1A-C). However, there were no significant changes in any of the organic carbon fractions in the NoSed+EPS coll, NoSed $+\mathrm{EPS}_{\mathrm{HB}}$, and NoAdd-EPS controls during the experiment (Figures 1A-C).

The value of $k$ for the three different carbon fractions (DOC, $\mathrm{TCHO}$, and cEPS) did not differ significantly within treatments, $+\mathrm{EPS}_{\text {coll }}$ and $+\mathrm{EPS}_{\mathrm{HB}}$ (Table 1). However, values of $k$ for DOC and cEPS fractions in the + EPS $_{\text {coll }}$ treatment were significantly higher than those calculated for $+\mathrm{EPS}_{\mathrm{HB}}$ treatment. Values of $k$ for the TCHO fraction between $+\mathrm{EPS}_{\text {coll }}$ and $+\mathrm{EPS}_{\mathrm{HB}}$ treatments were not statistically different (Table 1). The linear degradation rates of cEPS in both + EPS $_{\text {coll }}$ and + EPS $_{\mathrm{HB}}$ treatments were significantly lower than those of DOC and TCHO $(p<0.05$, ANCOVA).

The lower value of $k$ for the three carbon fractions in the $+\mathrm{EPS}_{\mathrm{HB}}$ treatment indicated a lower degradability that must be based in chemical differences between these fractions derived from the EPS ${ }_{\text {coll }}$ or the EPS $\mathrm{HB}_{\mathrm{HB}}$ enrichments. To address possible changes in the overall chemical composition in the added organic fractions, $\mathrm{EPS}_{\text {coll }}$ or the $\mathrm{EPS}_{\mathrm{HB}}$, we calculated the TCHO:DOC, cEPS:DOC, and cEPS:TCHO mass ratios in both enrichments (Supplementary Figure S1). These ratios were similar at day 0 for both enrichments, with observed differences not statistically significant. In general, both TCHO:DOC and cEPS:DOC remained constant or gradually decreased during the experiment in both enrichments. On the contrary cEPS:TCHO ratio in the $\mathrm{EPS}_{\mathrm{HB}}$ enrichment increased significantly (linear correlation; $r^{2}=0.9664 ; p<0.02$ ) with time, suggesting a lower relative degradability of cEPS material within the $+\mathrm{EPS}_{\mathrm{HB}}$ enrichment.

\section{Changes of Dissolved Inorganic Nutrients}

The EPS ${ }_{\text {coll }}$ and EPS $\mathrm{HB}_{\mathrm{H}}$ fractions added to the enrichments and the sediment inoculum contributed to the initial concentration of dissolved inorganic nutrients measured in the different treatments. These concentrations of nutrients, directly added with the EPS and sediment inoculum, were relatively low for all investigated nutrients at day $0\left(\mathrm{NO}_{3}^{-}+\mathrm{NO}_{2}^{-}<6.5 \mu \mathrm{mol} \mathrm{L}{ }^{-1}\right.$, $\mathrm{NH}_{4}^{+}<18.8 \mu \mathrm{mol} \mathrm{L}{ }^{-1}, \mathrm{PO}_{4}^{3-}<31.0 \mu \mathrm{mol} \mathrm{L}{ }^{-1}$, and $\mathrm{SiO}_{4}^{4-}<$ $\left.2.3 \mu \mathrm{mol} \mathrm{L}^{-1}\right)$. The general trend was an increase of all nutrients in all treatments with time (Figure 2). This increase over time is necessarily the result of the net regeneration of inorganic nutrients from the mineralization of the EPS fractions and/or the organic matter introduced with the sediment inoculum.

Concentrations of Dissolved Inorganic Nitrogen (DIN, the sum of nitrate, nitrite and ammonium concentrations) increased steeply with time in $+\mathrm{EPS}_{\mathrm{HB}}$ treatment $\left(24.6 \mu \mathrm{mol} \mathrm{L}^{-1} \mathrm{day}^{-1}\right)$, while the regeneration rates were significantly lower (SNK test, $p<0.05)$ in the rest of the treatments $\left(1.5-6.5 \mu \mathrm{mol} \mathrm{L}^{-1} \mathrm{day}^{-1}\right)$. There were no significant differences in DIN regeneration rates between + EPS $_{\text {coll }}$ and NoAdd-EPS treatments that were 6.5 and $5.5 \mu \mathrm{mol} \mathrm{L}{ }^{-1} \mathrm{day}^{-1}$, respectively (Figure 2A). The mineralization of the $\mathrm{EPS}_{\mathrm{HB}}$ fraction was a major source of DIN regeneration, initially in the form of $\mathrm{NH}_{4}^{+}$and later in the form of $\mathrm{NO}_{3}^{-}+\mathrm{NO}_{2}^{-}\left(\mathrm{NO}_{\mathrm{x}}^{-}\right)$(Supplementary Figure S2). The importance of the net regeneration of ammonium and $\mathrm{NO}_{\mathrm{x}}^{-}$ shifted during the experiment as shown by changes in $\mathrm{NO}_{\mathrm{x}}^{-}$: $\mathrm{NH}_{4}^{+}$ratio, which increased from about 0.15 at day 3 up to 3.3 at day 9. The regeneration rate of $\mathrm{NH}_{4}^{+}$at the beginning of the experiment was similar in both $+\mathrm{EPS}_{\mathrm{HB}}$ treatment and the $+\mathrm{EPS}_{\mathrm{HB}}$ control without sediment $\left(8.6-9.6 \mu \mathrm{mol} \mathrm{L}^{-1}\right.$ day $^{-1}$ ) and considerably higher than in the other treatments (1.8$3.3 \mu \mathrm{mol} \mathrm{L}^{-1} \mathrm{day}^{-1}$ ). This emphasizes the strong difference between $\mathrm{EPS}_{\mathrm{HB}}$ and $\mathrm{EPS}_{\text {coll }}$ regarding their potential as sources of regenerated inorganic nitrogen.

The EPS $_{\mathrm{HB}}$ fraction was a major source of regenerated dissolved phosphate, since its concentration increased in both treatments with added $\mathrm{EPS}_{\mathrm{HB}}\left(+\mathrm{EPS}_{\mathrm{HB}}\right.$ and NoSed $\left.+\mathrm{EPS}_{\mathrm{HB}}\right)$ at a similar rate $\left(4.9-5.9 \mu \mathrm{mol} \mathrm{L} \mathrm{L}^{-1} \mathrm{day}^{-1}\right)$ up to the day 6 (Figure 2B). Dissolved phosphate decreased significantly between days 6 and 9 in the $+\mathrm{EPS}_{\mathrm{HB}}$ treatment (SNK, $p<0.05)$ but not in the NoSed $+E^{2} S_{\mathrm{HB}}$ control. On the contrary, phosphate changed little or even decreased during the experiment in treatments with EPS $_{\text {coll }}$ or sediment only. 
TABLE 1 | Comparison of degradation constant ( $k$ ) calculated using the one-G model for degradation of organic matter (Berner, 1964) or the lineal degradation constant $(b)$ for the three carbon fractions measured [Dissolved Organic Carbon (DOC), Total Carbohydrates (TCHO) and colloidal EPS (cEPS)] in the $+\mathrm{EPS}_{\mathrm{coll}}$ and $+\mathrm{EPS}_{\mathrm{HB}}$ treatments during the 9-day period ( \pm standard error of $k$ and $b$ ).

\begin{tabular}{|c|c|c|c|c|}
\hline \multirow[t]{2}{*}{ Fraction } & \multicolumn{2}{|r|}{$+\mathrm{EPS}_{\text {coll }}$} & \multicolumn{2}{|c|}{$+\mathrm{EPS}_{\mathrm{HB}}$} \\
\hline & $k\left(\mathrm{~d}^{-1}\right)$ & $b\left(m g C_{o r g} g^{-1}\right.$ sed. WW d $\left.d^{-1}\right)$ & $k\left(d^{-1}\right)$ & $b\left(\mathrm{mg} \mathrm{C}_{\text {org }} \mathrm{g}^{-1}\right.$ sed. WW d $\left.{ }^{-1}\right)$ \\
\hline Dissolved Organic Carbon (DOC) & $0.105^{a} \pm 0.01$ & $1.19 \pm 0.18$ & $0.060^{b} \pm 0.005$ & $0.84^{a} \pm 0.08$ \\
\hline Total Carbohydrates (TCHO) & $0.123^{a} \pm 0.02$ & $0.81^{a, b} \pm 0.19$ & $0.096^{a, b} \pm 0.02$ & $0.68^{a} \pm 0.16$ \\
\hline Colloidal EPS (cEPS) & $0.121^{\mathrm{a}} \pm 0.007$ & $0.44^{b} \pm 0.03$ & $0.062^{b} \pm 0.01$ & $0.36^{b} \pm 0.07$ \\
\hline
\end{tabular}

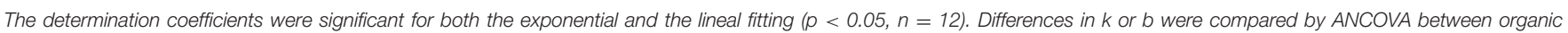

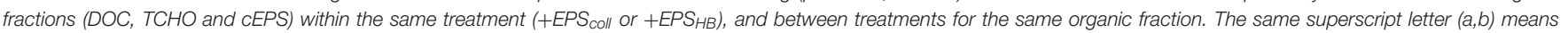
absence of statistically significant differences among the corresponding values of $k$ or $b(p<0.05)$.

Silicate concentrations increased with time, particularly from day 3 onwards in all of the treatments with added sediment, $+\mathrm{EPS}_{\text {coll }},+\mathrm{EPS}_{\mathrm{HB}}$, and NoAdd-EPS treatments (Figure 2C). The regeneration of silicate was positively affected by the sediment inoculum, since it was higher in all the treatments

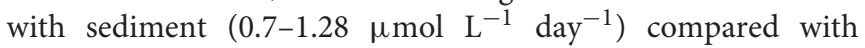
NoSed + EPS $_{\text {coll }}$ and NoSed + EPS $_{\mathrm{HB}}$ controls lacking sediment inoculum, 0.16 and $0.41 \mu \mathrm{mol} \mathrm{L}^{-1} \mathrm{day}^{-1}$, respectively. This likely indicates that the sediment inoculum was the source of regenerated silicate during the experiment and not the added EPS.

\section{Changes in DNA Concentration of Sediment Slurries}

Extracted DNA concentration was used as a proxy for microbial biomass (Figure 3). At the beginning of the experiment, there were no significant differences between DNA concentrations in the $+\mathrm{EPS}_{\mathrm{coll}},+\mathrm{EPS}_{\mathrm{HB}}$, and NoAdd-EPS treatments (Figure 3). DNA concentration increased significantly (by around 400\%) in the $+\mathrm{EPS}_{\text {coll }}$, and $+\mathrm{EPS}_{\mathrm{HB}}$ treatments by the end of the experiment (SNK, $p<0.05$ ). In the NoAdd-EPS sedimentonly control DNA concentration decreased by day 9 compared to day 0 , with concentrations significantly lower than in the organic-carbon-amended treatments $\left(+\mathrm{EPS}_{\text {coll }}\right.$ and $\left.+\mathrm{EPS}_{\mathrm{HB}}\right)$ (SNK, $p<0.001)$. Microbial biomass exhibited exponentiallike growth in the treatments $+\mathrm{EPS}_{\mathrm{coll}}$ and $+\mathrm{EPS}_{\mathrm{HB}}\left(r^{2}=0.84\right.$ and $r^{2}=0.56$, respectively), and no significant differences were observed between these two treatments.

\section{Changes in the Bacterial Community Composition}

Denaturing gradient gel electrophoresis (DGGE) of partial bacterial 16S rRNA genes (Supplementary Figure S3) showed consistency in the banding patterns between replicate treatments at day 9 , and showed that the day- 0 communities were identical regardless of treatment, justifying the use of the day- $0+\mathrm{EPS}_{\mathrm{coll}}$ treatment only in subsequent pyrosequence analysis. By day- 9 the bacterial community composition had changed from day0 even in the NoAdd-EPS control, and at day-9 there were distinct differences in bacterial community composition between the treatments $+\mathrm{EPS}_{\text {coll }},+\mathrm{EPS}_{\mathrm{HB}}$, and NoAdd-EPS.

In order to quantify the changes in bacterial community composition and identify key taxa putatively involved in EPS degradation, pyrosequencing of $16 \mathrm{~S}$ rRNA genes was performed on $+\mathrm{EPS}_{\text {coll }},+\mathrm{EPS}_{\mathrm{HB}}$ and NoAdd-EPS treatments after 9 days, and from a representative day-0 sample, $+\mathrm{EPS}_{\text {coll }}$. Multidimensional scaling analysis revealed statistically significant temporal- and treatment-related changes (Figure 4). The bacterial communities from day- $9+$ EPS $_{\text {coll }}$ and + EPS $_{\mathrm{HB}}$ treatments were different from both the NoAdd-EPS treatment at day 9 and the starting community $(p<0.05)$ (Figure 4). After 9 days, the NoAdd-EPS community was more similar to the starting community than those with added EPS. Also, there was a significant difference $(p<0.05)$ in the bacterial community composition between the $+\mathrm{EPS}_{\mathrm{coll}}$ and $+\mathrm{EPS}_{\mathrm{HB}}$ treatments at day 9.

The only phyla that were significantly enriched at day-9 in the + EPS $_{\text {coll }}$ treatment compared with the NoAdd-EPS control were the Bacteroidetes ( $\sim 2$-fold more abundant) and Verrucomicrobia ( $\sim 5$-fold more abundant; data not shown). These enrichments were specifically within the Sphingobacteria (Bacteroidetes), two classes from Verrucomicrobia (Verrucomicrobiae and Opitutae) and one class of Planctomycetes (Phycisphaerae), which were all significantly more abundant in the $+\mathrm{EPS}_{\text {coll }}$ treatment (Figure 5A; see figure for statistical criteria). At the level of operational taxonomic units clustering at $95 \%$ similarity $\left(\mathrm{OTU}_{95}\right)$, OTU-2960, from the genus Tenacibaculum in the phylum Bacteroidetes, had the biggest additive increase in the treatment $+\mathrm{EPS}_{\text {coll }}(12 \%$ relative abundance) compared with NoAdd-EPS (5\%; Figure 5B). The Verrucomicrobia OTU-9279 increased most in relative abundance, constituting $3 \%$ of the community in treatment + EPS $_{\text {coll }}$ while in the NoAdd-EPS control it was absent (Figure 5B).

Bacteroidetes and Verrucomicrobia were also significantly enriched at day- 9 in the + EPS $_{\mathrm{HB}}$ treatment compared with the NoAdd-EPS control ( $\sim 2.5$-fold and $\sim 6$-fold more abundant respectively; data not shown). At the subphylum level, only Flavobacteria and Sphingobacteria from the Bacteroidetes were enriched significantly (Figure 6A). As with the $+\mathrm{EPS}_{\text {coll }}$ treatment, there was a big increase in OTU-2960 from the genus Tenacibaculum (phylum Bacteroidetes) comprising $20 \%$ of the relative abundance (Figure 6B). OTU-7700, with $100 \%$ identity to Algoriphagus yeomjeoni from the phylum Bacteroidetes and OTU-2464 from the gammaproteobacterial 

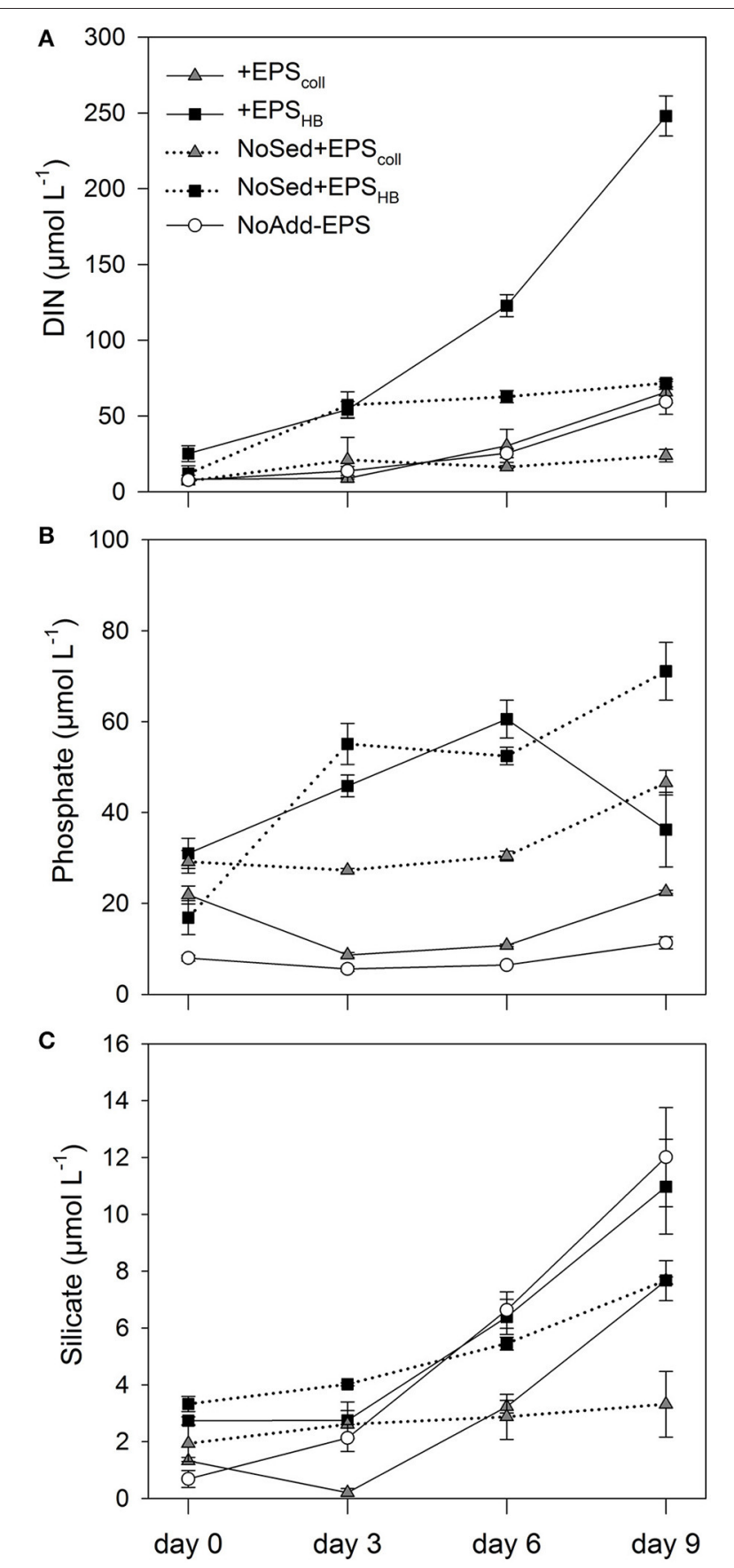

FIGURE 2 | Concentrations of different inorganic nutrients measured: Nitrate, Nitrite and Ammonium expressed as Dissolved Inorganic Nitrogen (DIN) (A), Phosphate (B), and Silicate (C) in estuarine sediment slurries (200 mg from the top $2 \mathrm{~mm}, 80 \mathrm{~mL}$ artificial sea water (ASW) over 9 days) for the treatments + EPS $_{\mathrm{Coll}},+\mathrm{EPS}_{\mathrm{HB}}$, NoAdd-EPS and the controls (no sediment added), NoSed+EPS coll $_{\text {and NoSed+EPS }}$ HB represented with dotted lines. Values are means $(n=3) \pm$ standard error (SE), expressed as $\mu \mathrm{mol} \mathrm{L} \mathrm{L}^{-1}$ of slurry.

genus Amphritea, both had the biggest relative increase after $\mathrm{EPS}_{\mathrm{HB}}$ addition, and comprised $\sim 3 \%$ of the day- $9+\mathrm{EPS}_{\mathrm{HB}}$ community (Figure 6B).

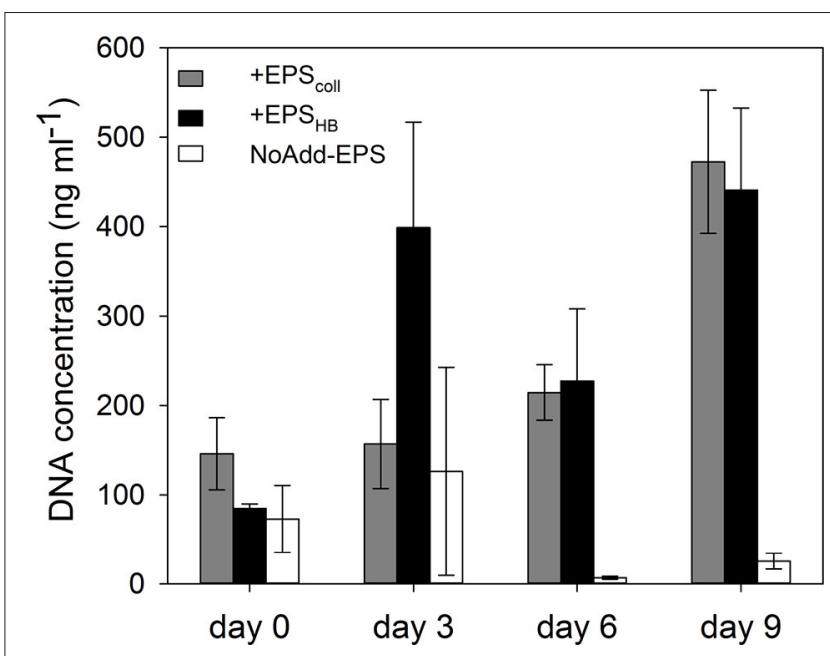

FIGURE 3 | DNA concentration (as a proxy for biomass) in estuarine sediment slurries for the treatments $+\mathrm{EPS}_{\mathrm{coll}},+\mathrm{EPS}_{\mathrm{HB}}$, and NoAdd-EPS, expressed as $\mathrm{ng} \mathrm{mL}^{-1}$ of slurry.

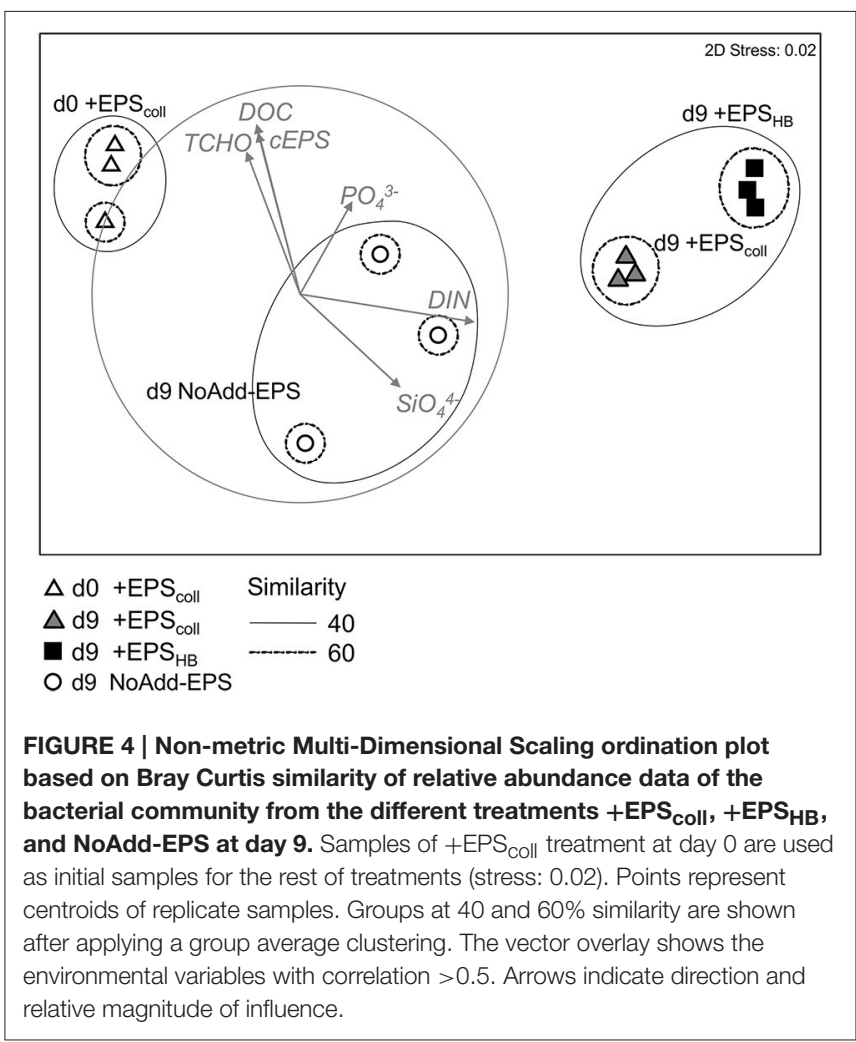

Bacterial communities from + EPS $_{\text {coll }}$ and + EPS $_{\mathrm{HB}}$ treatments were $52 \%$ similar but significantly different (Figure 4, $p<0.05$ ). There were no phylum-level significant differences in abundance between these two treatments. However, the addition of EPS $_{\text {coll stimulated significant }}$ increases in Opitutae from the phylum Verrucomicrobia and in Deltaproteobacteria as the only identified classes compared to $\mathrm{EPS}_{\mathrm{HB}}$-amended treatment $\left(+\mathrm{EPS}_{\mathrm{HB}}\right.$ treatment) 
(Supplementary Figure S4A). Three aforementioned OTUs belonging to the genera Tenacibaculum, Amphritea, and Algoriphagus were significantly relatively more abundant in $+\mathrm{EPS}_{\mathrm{HB}}$, whereas a range of OTUs from diverse phyla was relatively more abundant in + EPS $_{\text {coll }}$ (Supplementary Figure S4B).

\section{Relationship between the Bacterial Community Composition and Environmental Variables}

Pearson correlation biplots drawn on the MDS showed that DIN correlated strongly with the horizontal axis, separating the day 9 bacterial communities of $+\mathrm{EPS}_{\text {coll }}$ and $+\mathrm{EPS}_{\mathrm{HB}}$ treatments from the initial samples. cEPS and the rest of the organic carbon source related variables (TCHO; DOC) had a high correlation with the second axis, which separates both + EPS $_{\text {coll }}$ and + EPS $_{\mathrm{HB}}$ treatments from NoAdd-EPS treatment.

\section{DISCUSSION}

\section{Degradation of Colloidal EPS by Heterotrophic Bacteria}

The degradation of organic matter is a chemically and microbiologically complex process because organic matter is typically a mixture of organic compounds with different relative degradability (Hedges and Oades, 1997; Burdige, 2007; Arndt et al., 2013). Microbial degradation involves the extracellular breakdown of HMW polymers to LMW oligosaccharides and monomers (Goto et al., 2001; Hofmann et al., 2009), which can be readily incorporated by bacterial cells, with the initial polymer hydrolysis generally being the rate-limiting step (Meyer-Reil, 1990; Kristensen and Holmer, 2001). In our experiment, addition of EPS stimulated the degradation of the organic fractions (DOC, TCHO, and cEPS) in both $+\mathrm{EPS}_{\text {coll }}$ and + EPS $_{\mathrm{HB}}$ treatments (Figure 1). Ratios of cEPS:DOC and TCHO:DOC decreased consistently in both treatments, which might indicate a preferential degradation of cEPS and TCHO compared to DOC. On the other hand, the difference in the time evolution of cEPS:TCHO ratios between treatments suggests a lower degradability of cEPS from the hot-bicarbonate fraction. Typically, most slurry studies have found that the hotbicarbonate carbohydrate fraction is more refractory that the cEPS fraction in oxic conditions (Table 2).

Organic matter degradation in marine sediments usually follows an exponential decay with time described by the Gmodels family (Berner, 1964; Arndt et al., 2013). Only a few studies have applied this model in EPS-related studies. Oakes et al. (2010) studying the degradation rates of several monosaccharide pools applied a $2-\mathrm{G}$ model which assumes that the pool of organic matter consists of two fractions that degrade exponentially at different rates and included a non-reactive fraction as well. Three fractions in each monosaccharide pool were detected: (1) a highly labile fraction accounting for the largest part (65-87\%) of each monosaccharide pool, with high exponential decay rates $(k)\left(0.81-4.38 \mathrm{~d}^{-1}\right) ;(2)$ a more refractory fraction (7-18\% of each monosaccharide pool), whose $k$ was one or two order of magnitude lower (0.01-0.07 $\left.\mathrm{d}^{-1}\right)$; and (3) a nonreactive fraction (6-23\% of each monosaccharide pool) (Table 2). The presence of a second most refractory component was evident in the degradation kinetics of various sediment-extracted carbohydrate fractions both in oxic and anoxic conditions in a 25-day slurry experiment (McKew et al., 2013). Although the loss of TCHO and cEPS over time in our experiment could suggest the existence of a second more refractory component (especially in the $+\mathrm{EPS}_{\mathrm{HB}}$ treatment), testing for the inclusion of such a component in the model did not provide a significantly better fit (results not shown). It is probable that the time scale of our experiment was too short to detect the existence of more than one pool in the degradation kinetics of every fraction.

The exponential decay rates in our experiment (Table 1) fall between those of the highly reactive fraction and the less reactive fraction of Oakes et al. (2010) for specific monosaccharides. However, the exponential decay rates from the current study for specific carbohydrates and more complex or less unambiguously defined carbohydrate-related fractions, like TCHO and EPS, extracted from microbenthic algae (this study, Goto et al., 2001; Oakes et al., 2010), span two orders of magnitude (Table 2). Interestingly, these rates are higher and less variable than the wider range of reported $k$-values $\left(10^{-11}-10^{-2} \mathrm{~d}^{-1}\right)$ for the degradation of bulk organic matter in different marine sediments (Arndt et al., 2013). This indicates the general lability of diatom-biofilm EPS in comparison to detritus derived from other sources, and highlights its importance in structuring heterotrophic communities (Hofmann et al., 2009; Taylor et al., 2013). However, comparison of degradation rate constants between different experiments or different environments must be done with caution since the degradability of organic matter depends on the interaction of its chemical composition and the particular environmental conditions where degradation takes place (Mayer, 1995; McKew et al., 2013).

\section{EPS Degradation and Inorganic Nutrient Regeneration}

Nutrient concentrations detected on day 0 were higher in all treatments with added EPS compared to the control. Although the sediment inoculum added may have represented a small source of inorganic nutrients to the slurries, it seems that both EPS-extraction methods recover some dissolved inorganic nutrients from the sediment plus microphytobenthic biofilm samples, a source of nutrients not previously accounted for (Figure 2). The extraction protocol of both EPS fractions involves freezing the sediment sample, which is known to break algal and bacterial cells releasing relatively large amounts of intracellular dissolved inorganic nutrients (García-Robledo et al., 2010, 2016; Stief et al., 2013; Yamaguchi et al., 2015). Although, there were no significant differences on day 0 between nutrients in the $+\mathrm{EPS}_{\text {coll }}$ and + EPS $_{\mathrm{HB}}$ treatments, the hot-bicarbonate method extracted an organic matter pool that was particularly rich in organic $\mathrm{N}$ and $\mathrm{P}$ (Figure 2, Supplementary Figure S2). Increases in dissolved inorganic nutrients during the experiment were more pronounced and rapid with added $\mathrm{EPS}_{\mathrm{HB}}$ than for $+\mathrm{EPS}_{\mathrm{coll}}$, and 


\section{A Subphylum (Class) level}
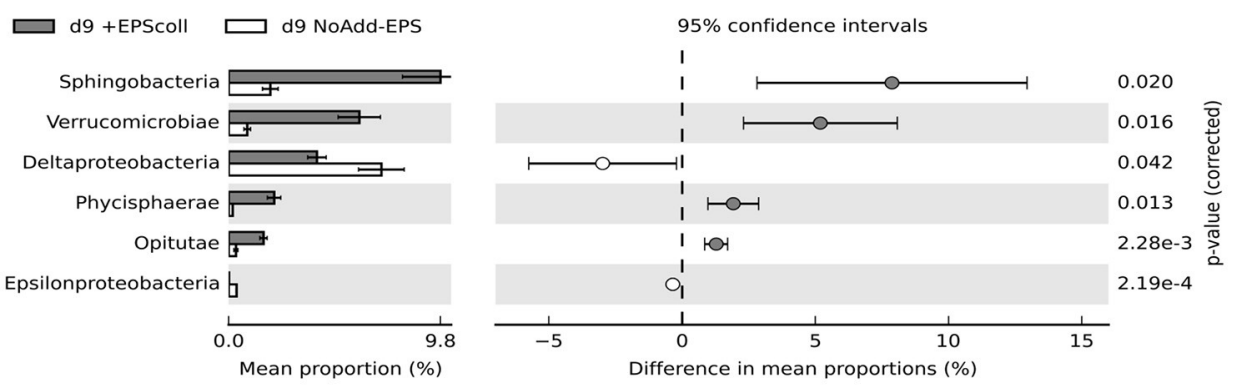

B Operational Taxonomic Unit (OTU) level

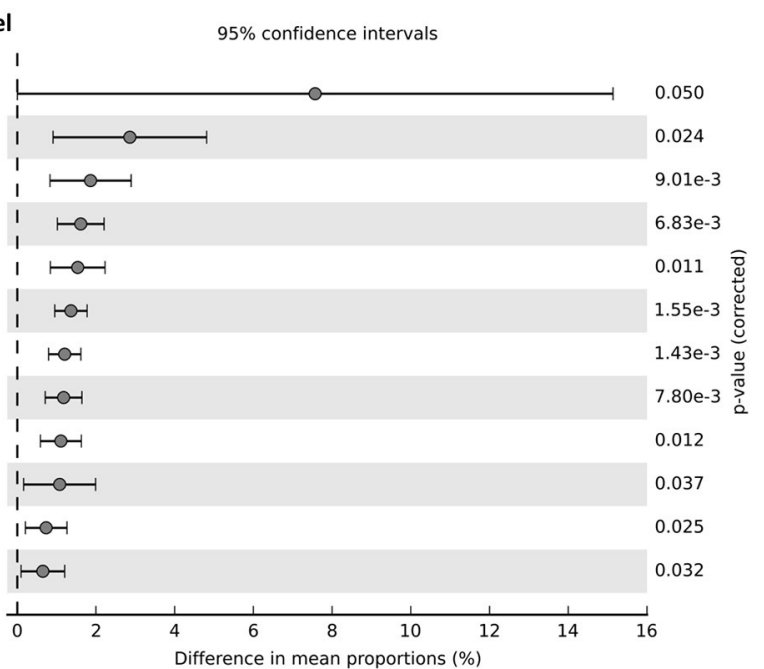

Bact, Tenacibaculum

Verr, Verrucomicrobiaceae

Plan, Rhodopirellula

Plan, Planctomyces

Bact, Algoriphagus

Bact, Lewinella

Bact, Gaetbulibacter

Plan, Phycisphaera

Bact, Cyclobacterium

AP, Alphaproteobacteria

$\mathrm{AP}$, Rhodobacteraceae

Plan, Planctomyces

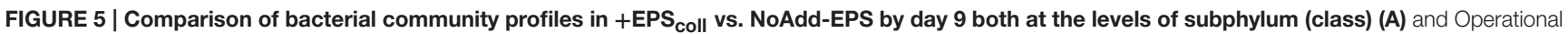
Taxonomic Unit (OTU) defined at >95\% similarity (B). Analysis was performed using STAMP (Parks and Beiko, 2010; Parks et al., 2014) with default parameters except that parameters for filtering out were: $p>0.05$; difference between proportions $<0.2$ or difference between ratios $<1.5$. Data were sorted according to effect size. Note the differences in the scale of the $x$ axes. The only phyla that were significantly enriched at day-9 in EPS control were the Bacteroidetes ( $\sim 2$-fold more abundant) and Verrucomicrobia ( 5 -fold more abundant; data not shown). The information to the right of the $p$-values is the identity of the OTU, whereby the phylum is indicated to the left of the comma (AP, Alphaprotebacteria; Bact, Bacteroidetes; Plan, Planctomycetes; Verr, Verrucomicrobia), and the lowest taxonomic level to which the OTU can be confidently assigned is indicated to the right of the comma. A total of 23 bacterial taxa was significantly enriched in +EPS coll treatment compared with NoAdd-EPS treatment but only the top 12 is shown.

represent the mineralization of nutrients associated to organic compounds included in the EPS $S_{\mathrm{HB}}$ fraction. EPS $\mathrm{HB}_{\mathrm{HB}}$ is one of the more abundant and heterogeneous fractions (Chiovitti et al., 2003) the extraction procedure of which not only recovers the extracellular carbohydrates but also uronic acids, proteins, glycoproteins, and phospholipids tightly bound to the mucilage of the diatom frustules (Underwood et al., 1995; Wustman et al., 1997).

The regeneration rate of $\mathrm{NH}_{4}^{+}$was similar in both treatments with EPS $_{\mathrm{HB}}$, with and without sediment, suggesting a wider distribution of this trait such that the presence of the sediment microbial community plays a minor role in this process. On the contrary, further transformation of $\mathrm{NH}_{4}^{+}$to $\mathrm{NO}_{2}^{-}$and $\mathrm{NO}_{3}^{-}$, detected in the $+\mathrm{EPS}_{\mathrm{HB}}$ treatment, particularly toward the end the experiment (Figure 2A, Supplementary Figure S2B), can be only explained by an increase of nitrification rates due to the growth of a community of nitrifiers introduced with the sediment inoculum, that was absent in the control without sediment. Nitrifying bacteria were indeed present in our samples (e.g., Nitrospira, which oxidizes nitrite to nitrate, and the ammoniaoxidizing genus Nitrosospira), albeit in low relative abundance $(\sim 0.01 \%)$ in the + EPS $_{\mathrm{HB}}$ treatment.

$\mathrm{EPS}_{\mathrm{HB}}$ was also an important source of regenerated $\mathrm{PO}_{4}^{3-}$. The initial stoichiometry between $\mathrm{NH}_{4}^{+}$and $\mathrm{PO}_{4}^{3-}$ regeneration rates was about 1.7 in both $\mathrm{EPS}_{\mathrm{HB}}$ treatments, considerably richer in $\mathrm{P}$ than typical microphytobenthic biomass (Hillebrand and Sommer, 1999). MPB biofilm $\mathrm{EPS}_{\mathrm{HB}}$ extractions do frequently include some ribose, indicating some DNA/RNA contamination (Bellinger et al., 2005, 2009), which may be the source of the phosphate. The decrease of $\mathrm{NH}_{4}^{+}$and $\mathrm{PO}_{4}^{3-}$ from day 6 to 9 in the $+\mathrm{EPS}_{\mathrm{HB}}$ treatment might be explained by higher microbial consumption rate at the end of the experiment. Nonetheless, growth of the microbial community, as estimated from the increase in DNA over 9 days, was similar in both 
A Subphylum (Class) level
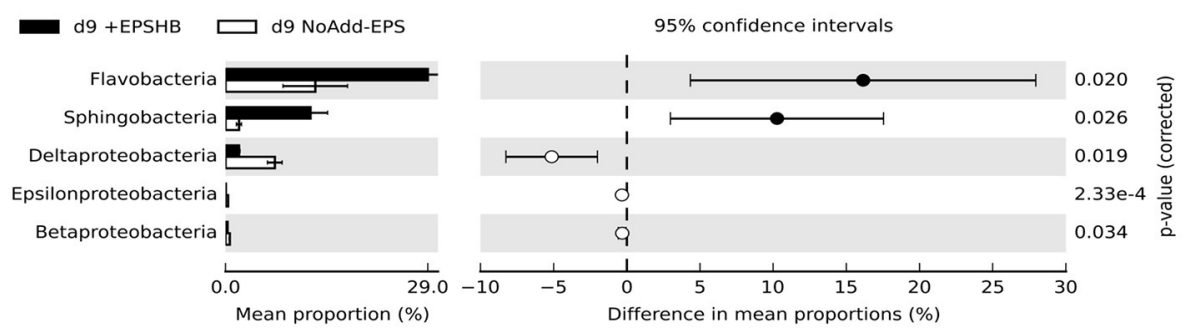

B Operational Taxonomic Unit (OTU) level

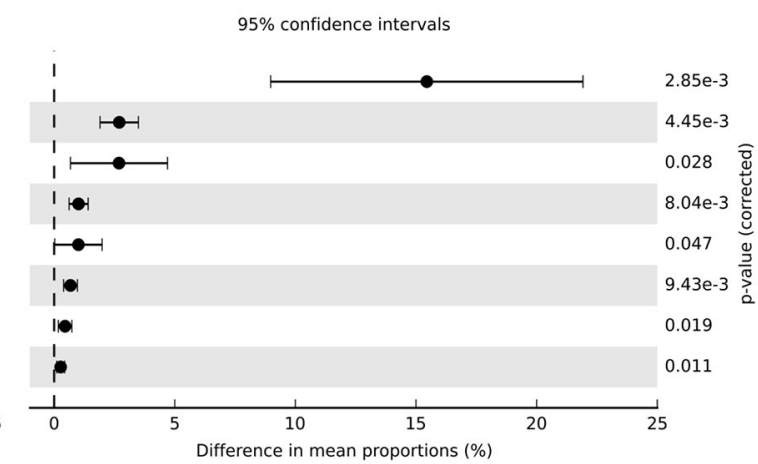

Bact, Tenacibaculum

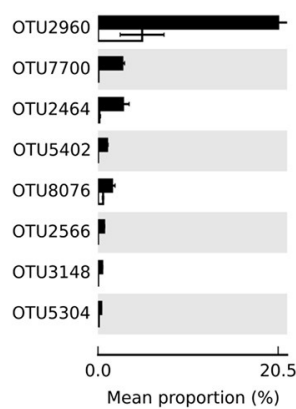

Bact, Algoriphagus

GP, Amphritea

Bact, Arenibacter

AP, Sulfitobacter

AP, Alphaproteobacteria

Verr, Verrucomicrobia

Verr, Roseibacillus

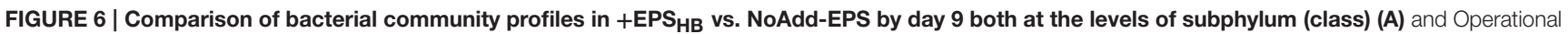
Taxonomic Unit (OTU) defined at >95\% similarity (B). Analysis was performed using STAMP (Parks and Beiko, 2010; Parks et al., 2014) with default parameters except that parameters for filtering out were: $p>0.05$; difference between proportions $<0.2$ or difference between ratios $<1.5$. Data were sorted according to effect size. Note the differences in the scale of the $x$ axes. The only phyla that were significantly enriched at day- 9 in EPS $S_{H B}$ treatment compared with the NoAdd-EPS control were the Bacteroidetes ( 2.5 -fold more abundant) and Verrucomicrobia ( 6-fold more abundant; data not shown). The information to the right of the $p$-values is the identity of the OTU, whereby the phylum is indicated to the left of the comma (AP, Alphaprotebacteria; Bact, Bacteroidetes; GP, Gammaproteobacteria; Verr, Verrucomicrobia), and the lowest taxonomic level to which the OTU can be confidently assigned is indicated to the right of the comma. A total of eight bacterial taxa were significantly enriched in +EPS $\mathrm{HB}_{\mathrm{B}}$ treatment compared with NoAdd-EPS treatment.

$+\mathrm{EPS}_{\mathrm{HB}}$ and $+\mathrm{EPS}_{\text {coll }}$ treatments. Therefore, even the lower amount of regenerated nutrient released from the $\mathrm{EPS}_{\text {coll }}$ fraction was enough to support the microbial demand for $\mathrm{N}$ and $P$.

The regeneration rate of silicate was 3-4 times higher in the treatments with sediment-inoculum added compared to the controls without sediment inoculum (Figure 2C). Most likely the increase in silicate is mainly due to its regeneration from a particulate pool bound to sediment particles. Even in the absence of any added EPS, in the NoAdd-EPS treatment (with sediment), the regeneration of silicate was similar to that of the $+\mathrm{EPS}_{\mathrm{HB}}$ treatment with sediment. Therefore, EPS seems to play a minor role in the recycling of silicate in marine sediments in contrast to what we have shown for $\mathrm{N}$ and $\mathrm{P}$.

\section{EPS-Induced Changes in the Bacterial Community Composition}

Incubation of sediment slurries with both types of EPS resulted in a significant increase in microbial biomass by the end of the experiment using total DNA concentration as a proxy (Figure 3; Haynes et al., 2007). It also led to a significant shift in community composition, both temporally and as direct result of EPS addition (Figure 4). Given that EPS was the differentially added component, constituting a high proportion of the available DOC, and that its degradation was ongoing at day 9, the selectively enriched and actively growing microbial community at this time would contain a high proportion of active EPSdegraders. However, the dominance of such bacterial taxa is also the net result of the growth at the expense of the added EPS sources and any losses by grazing and viral lysis (Våge et al., 2013; Thingstad et al., 2014), which might have increased due to the increased inorganic nutrient content in the slurries (Miki and Jacquet, 2010). The relative similarity of many of the taxa comprising the bacterial communities in the $+\mathrm{EPS}_{\text {coll }}$ and $+\mathrm{EPS}_{\mathrm{HB}}$ treatments indicate that most EPS-degrading bacteria readily consume a wide range of diatom-derived EPS (Taylor et al., 2013). Nevertheless, the significant difference overall between communities fed with EPS $_{\text {coll }}$ and EPS $\mathrm{HB}_{\mathrm{HB}}$ indicates that there are a number of specialist bacteria that preferentially use a particular fraction.

Several bacterial phyla, namely Bacteroidetes, Verrucomicrobia and Planctomycetes, increased their presence in the + EPS $_{\text {coll }}$ compared with the NoAdd-EPS treatment, and were thus probably involved in $\mathrm{EPS}_{\text {coll }}$ biodegradation (Figure 5A). Verrucomicrobia is a phylum that is widely distributed, but rarely dominant (Freitas et al., 2012; Yilmaz et al., 2016). As there are few cultivated representatives of this 


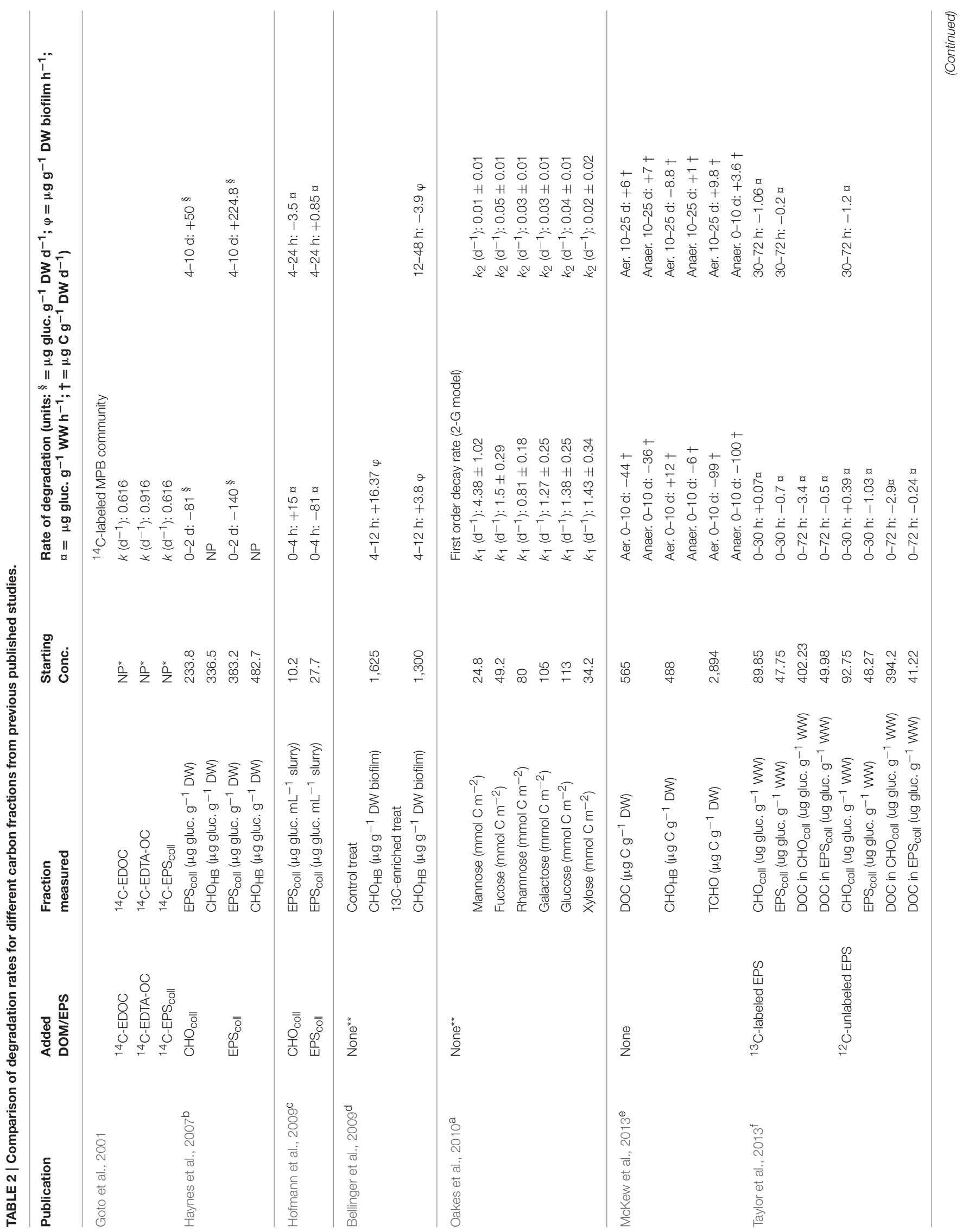




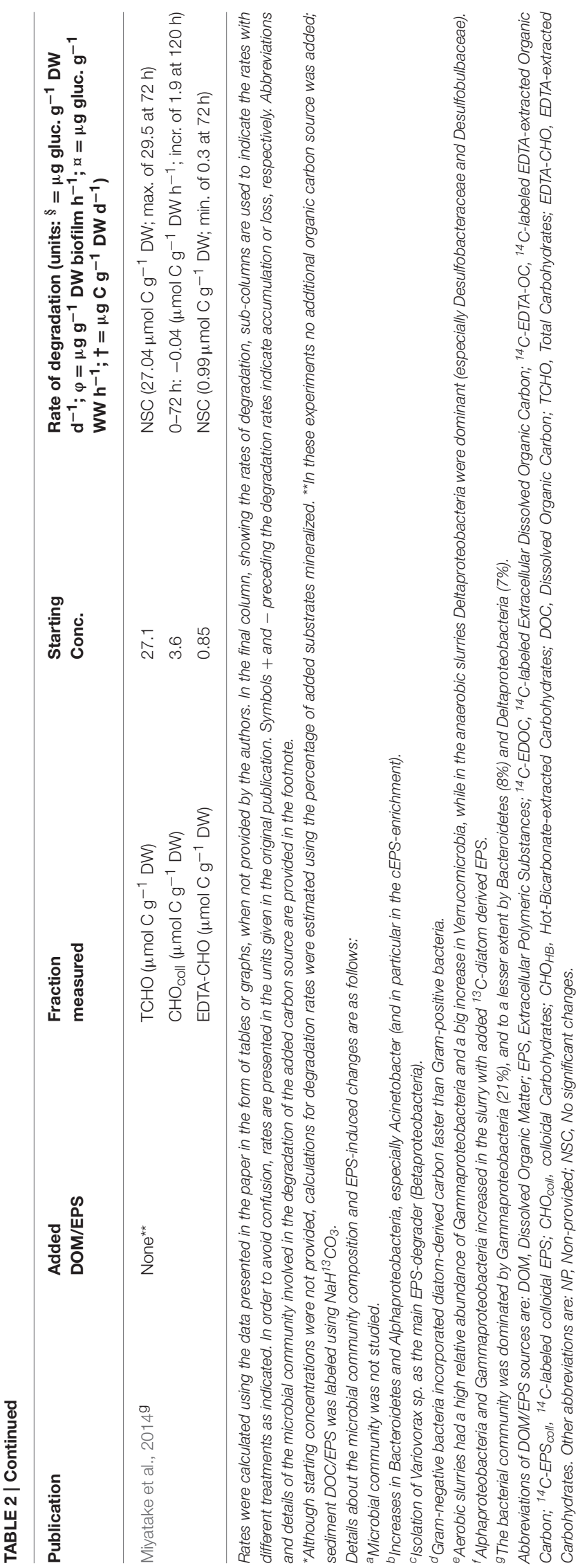

group, we have a poor understanding of its ecophysiology, but evidence is emerging that many species of Verrucomicrobia consume algal EPS and other biopolymers (Martinez-Garcia et al., 2012; Cardman et al., 2014; Landa et al., 2014; Orsi et al., 2016). McKew et al. (2013) showed that, in a mudflat enrichment, Verrucomicrobia had the biggest proportional increase $(\sim 6-$ fold) when incubated aerobically with cEPS, but were $\sim 40 \%$ less abundant when grown anaerobically. In addition, PiCrust analysis suggests that Verrucomicrobia have a similar range and number of extracellular enzymes for breaking down complex polymers as do the Bacteroidetes, a recognized major biopolymer-degrading group (Yilmaz et al., 2016). Specifically, a metagenome from the marine Candidatus Spartobacteria baltica was rich in glycoside hydrolases (Herlemann et al., 2013). Thus, a picture is emerging that aerobic biopolymer degradation is a key trait of many Verrucomicrobia. Verrucomicrobia were also significantly enriched in the presence of $\mathrm{EPS}_{\mathrm{HB}}$, suggesting that they are able to degrade complex polymers. Two OTUs had a marginal increase in abundance in the presence of $\mathrm{EPS}_{\mathrm{HB}}$, one of which was related to Roseibacillus, species of which have been isolated from brown algae and also from marine water and sediments (Yoon et al., 2008), which may further indicate interactions with photosynthetic organisms.

The phylum Bacteroidetes was significantly more abundant when incubated with $\mathrm{EPS}_{\mathrm{HB}}$ and with $\mathrm{EPS}_{\text {coll }}$. Unlike the Verrucomicrobia, the Bacteroidetes are well known for their capacity to degrade biopolymers, including EPS (Haynes et al., 2007; McKew et al., 2013). Many OTUs from diverse classes of Bacteroidetes were selectively enriched (Figures 5B, 6B), two of which were enriched under both EPS additions, but had a higher relative abundance with $\mathrm{EPS}_{\mathrm{HB}}$. One of these, from the genus Tenacibaculum, constituted $12 \%$ of the community with $\mathrm{EPS}_{\text {coll }}$ and $20 \%$ with $\mathrm{EPS}_{\mathrm{HB}}$, and has been shown to possess enzymes able to degrade a great range of organic compounds from a wide range of marine habitats including tidal flat sediments (Suzuki et al., 2001; Frette et al., 2004; Choi et al., 2006; Jung et al., 2006). The second Bacteroidetes OTU, 2-fold more abundant in $\mathrm{EPS}_{\mathrm{HB}}$ than $\mathrm{EPS}_{\text {coll }}$, was from the genus Algoriphagus, which is able to degrade an array of different compounds as carbon and energy sources (e.g., D-glucose, Dgalactose, sucrose) (Yoon et al., 2005; Alegado et al., 2013). This genus is normally found in diverse marine habitats, such as seawater, tidal mudflats, and salterns, and also associated with algae (Nedashkovskaya et al., 2004) or cyanobacterial mats (Bowman et al., 2003). Such features indicate that Algoriphagus species might be considered as specialist EPS/carbohydrate degraders.

Similarly to Verrucomicrobia, certain taxa within the phylum Planctomycetes are emerging as important biopolymerdegrading microbes (Wang et al., 2015; Yilmaz et al., 2016). They generally are enriched in marine snow (Fuchsman et al., 2012), are associated with macroalgae (Lage and Bondoso, 2011), and increase in abundance in coastal diatom blooms (Morris et al., 2006), suggesting that they may be able to utilize the released algal organic carbon. Here, Planctomycetes (class Phycisphaerae) was more abundant when grown on EPS 
compared to NoAdd-EPS, with three OTUs specifically enriched (Figure 5), but not when incubated with $\mathrm{EPS}_{\mathrm{HB}}$ compared to NoAdd-EPS (Figure 6). One of the most EPS $_{\text {coll-enriched }}$ OTUs was from the genus Rhodopirellula. Rhodopirellula baltica degrades carbohydrates in marine environments (Gade et al., 2005) and genome sequencing revealed its ability to degrade algal-derived sulfated polysaccharides (Glöckner et al., 2003; Wegner et al., 2013). However, in contrast to the current finding, previous studies performed in the Colne estuary using different approaches did not detect this Planctomycetes as a specialist EPS degrader (Hofmann et al., 2009; McKew et al., 2013; Taylor et al., 2013), thus further work is needed to clarify the role of this phylum in intertidal systems.

The relative similarity of many taxa in the $+\mathrm{EPS}_{\text {coll }}$ and + EPS $_{\mathrm{HB}}$ treatments could indicate that there is a general capability of utilizing EPS, in accordance with previous studies. Miyatake et al. (2014), for example, showed that of the bacterial taxa targeted all incorporated diatom-derived material. For the Colne, previous studies showed only small changes in overall bacterial community composition in response to added EPS using different approaches (Hanlon et al., 2006; Haynes et al., 2007; Bellinger et al., 2009). Taylor et al. (2013) demonstrated that a diverse range of bacterial taxa were enriched when exposed to cEPS, including highly enriched Alphaproteobacteria and Gammaproteobacteria, but of different lower-order taxa to those found here. Although our results cannot preclude uptake of EPS by a wide range of bacteria, which express this capacity depending on the particular environmental conditions or composition of EPS, the results of the present experiment show clear and consistent changes in the abundance of several taxa when incubated with added EPS. This is consistent with other studies (Hanlon et al., 2006; Haynes et al., 2007; Taylor et al., 2013) and demonstrates some specialization for degradation of different types of EPS $\left(\mathrm{EPS}_{\text {coll }}\right.$ and $\mathrm{EPS}_{\mathrm{HB}}$ ).

\section{CONCLUSIONS}

EPS constitute a large fraction of the available carbon and energy in marine sediments and wherever phototrophic microbes abound (Underwood et al., 2005; Bellinger et al., 2009). Here, we have shown that fractions of EPS with different structural complexity (operationally termed colloidal and hot-bicarbonate extracted) were degraded, at higher rates compared with those reported previously (Table 2), contributing to the transfer of organic C from microphytobenthos to heterotrophic bacteria. The comparison of degradation rate constants for the different organic fractions studied here, using a one-G exponential decay model, confirmed that DOC and cEPS fractions from the $+\mathrm{EPS}_{\mathrm{HB}}$ treatment are more refractory than their counterpart fraction in the $+\mathrm{EPS}_{\text {coll }}$ treatment (Table 1) in accordance with most studies, where higher molecular weight, complex compounds have a lower degradability (Table 2). In addition, our results indicate that EPS, particularly the EPS ${ }_{\mathrm{HB}}$ fraction, contain large amounts of $\mathrm{N}$ and $\mathrm{P}$ that may be released during EPS degradation at rates high enough to support microbial growth in slurries. The relevance of the EPS $\mathrm{HB}$ fraction as a source of regenerated nutrient, mainly $\mathrm{N}$ and $\mathrm{P}$, for the sediment microbial community in situ and the observed differences with respect to $\mathrm{EPS}_{\text {coll }}$ fraction require further investigation. The addition of different diatom-derived EPS also induced the enrichment of different bacterial taxa, indicating the existence of some specialization for degradation of different types of EPS. Given the widespread use of high-throughput amplicon sequencing, programs are being developed to infer microbial functions based on phylogeny. However, such approaches must be grounded on solid experimental evidence as presented here, considering the complex interactions of EPS degradation in sediments (Bellinger et al., 2009; McKew et al., 2013; Taylor et al., 2013). Further investigation is required to understand how changes in nutrient regeneration and EPS degradation rates and the differential enrichment of distinct taxa affect EPS budgets in intertidal sediments in situ, in relation to changes in the relative composition of EPS during a tidal or seasonal cycle.

\section{AUTHOR CONTRIBUTIONS}

All the authors designed the experiment. JB carried out the experiment and analyzed the samples. All authors analyzed and interpreted the data and wrote the manuscript.

\section{FUNDING}

The research was funded by Projects CTM-2009-10736, CTM2013-43857-R (Ministry of Economy and Competitiveness, Spain), and P11-RNM-7199 (Andalusian Regional Government). JB was funded by a FPI Grant (BES-2010-035711) from the Ministry of Economy and Competitiveness, Spain. GU and TM were funded by a NERC grant NE/K001914/1 (Data Synthesis and Management of Marine and Coastal Carbon).

\section{ACKNOWLEDGMENTS}

We thank Farid Benyahia, Tania Cresswell-Maynard, and John W. Green for their outstanding technical support at the University of Essex, Dr. Alex Dumbrell for bioinformatics support and Dave R. Clark for assistance with sequence submission.

\section{SUPPLEMENTARY MATERIAL}

The Supplementary Material for this article can be found online at: http://journal.frontiersin.org/article/10.3389/fmicb. 2017.00245/full\#supplementary-material 


\section{REFERENCES}

Acuña Alvarez, L., Exton, D. A., Timmis, K. N., Suggett, D. J., and McGenity, T. J. (2009). Characterization of marine isoprene-degrading communities. Environ. Microbiol. 11, 3280-3291. doi: 10.1111/j.1462-2920.2009.02069.x

Alegado, R. A., Brown, L. W., Cao, S., Dermenjian, R. K., Zuzow, R., Fairclough, S. R., et al. (2013). Algoriphagus machipongonensis sp. nov., co-isolated with a colonial choanoflagellate. Int. J. Syst. Evol. Microbiol. 63, 163-168. doi: 10.1099/ijs.0.038646-0

Anderson, M. J. (2001). A new method for non-parametric multivariate analyses of variance in ecology. Austral. Ecol. 26, 32-46. doi: 10.1111/j.1442-9993.2001.01070.pp.x

Anderson, M. J., and Robinson, J. (2003). Generalized discriminant analysis based on distances. Aust. N.Z. J. Stat. 45, 301-338. doi: 10.1111/1467-842X.00285

Arndt, S., Jørgensen, B. B., LaRowe, D. E., Middelburg, J. J., Pancost, R. D., and Regnier, P. (2013). Quantifying the degradation of organic matter in marine sediments: a review and synthesis. Earth Sci. Rev. 123, 53-86. doi: 10.1016/j.earscirev.2013.02.008

Arnosti, C. (2011). Microbial extracellular enzymes in the marine carbon cycle. Ann. Rev. Mar. Sci. 3, 401-425. doi: 10.1146/annurev-marine-120709142731

Aslam, S. N., Michel, C., Niemi, A., and Underwood, G. J. C. (2016). Patterns and drivers of carbohydrate budgets in ice algal assemblages from first year Arctic sea ice. Limnol. Oceanogr. 61, 919-937. doi: 10.1002/lno.10260

Beaumont, N. J., Jones, L., Garbutt, A., Hansom, J. D., and Toberman, M. (2014). The value of carbon sequestration and storage in coastal habitats. Estuar. Coast. Shelf Sci. 137, 32-40. doi: 10.1016/j.ecss.2013.11.022

Bellinger, B. J., Abdullahi, A. S., Gretz, M. R., and Underwood, G. J. C. (2005). Biofilm polymers: relationship between carbohydrate biopolymers from estuarine mudflats and unialgal cultures of benthic diatoms. Aquat. Microb. Ecol. 38, 169-180. doi: 10.3354/ame038169

Bellinger, B. J., Underwood, G. J. C., Ziegler, S. E., and Gretz, M. R. (2009). Significance of diatom-derived polymers in carbon flow dynamics within estuarine biofilms determined through isotopic enrichment. Aquat. Microb. Ecol. 55, 169-187. doi: 10.3354/ame01287

Berner, R. A. (1964). An idealized model of dissolved sulfate distribution in recent sediments. Geochim. Cosmochim. Acta 28, 1497-1503. doi: 10.1016/0016-7037(64)90164-4

Bowman, J. P., Nichols, C. M., and Gibson, J. A. E. (2003). Algoriphagus ratkowskyi gen. nov., sp. nov., Brumimicrobium glaciale gen. nov., sp. nov., Cryomorpha ignava gen. nov., sp. nov. and Crocinitomix catalasitica gen. nov., sp. nov., novel flavobacteria isolated from various polar habitats. Int. J. Syst. Evol. Microbiol. 53, 1343-1355. doi: 10.1099/ijs.0.02553-0

Burdige, D. J. (2007). The preservation of organic matter in marine sediments: controls, mechanisms and an imbalance in sediment organic carbon budgets? Chem. Rev. 107, 467-485. doi: 10.1021/cr050347q

Cardman, Z., Arnosti, C., Durbin, A., Ziervogel, K., Cox, C., Steen, A. D., et al. (2014). Verrucomicrobia are candidates for polysaccharide-degrading bacterioplankton in an arctic fjord of Svalbard. Appl. Environ. Microbiol. 80, 3749-3756. doi: 10.1128/AEM.00899-14

Chiovitti, A., Higgins, M. J., Harper, R. E., and Wetherbee, R. (2003). The complex polysaccharides of the raphid diatom Pinnularia viridis (Bacilliariophyceae). J. Phycol. 39, 543-554. doi: 10.1046/j.1529-8817.2003.02162.x

Choi, D. H., Kim, Y.-G., Hwang, C. Y., Yi, H., Chun, J., and Cho, B. C. (2006). Tenacibaculum litoreum sp. nov., isolated from tidal flat sediment. Int. J. Syst. Evol. Microbiol. 56, 635-664. doi: 10.1099/ijs.0.64044-0

Decho, A. W. (1990). Microbial exopolymer secretions in ocean environments: their role(s) in food webs and marine processes. Oceanogr. Mar. Biol. Ann. Rev. 28, 73-153.

Dubois, M., Gilles, K. A., Hamilton, J. K., Rebers, P. A., and Smith, F. (1956). Colorimetric method for determination of sugars and related substances. Anal. Chem. 28, 350-356. doi: 10.1021/ac60111a017

Elifantz, H., Malmstrom, R. R., Cottrel, M. T., and Kirchman, D. L. (2005). Assimilation of polysaccharides and glucose by major bacterial groups in the Delaware Estuary. Appl. Environ. Microbiol. 71, 7799-7805. doi: 10.1128/AEM.71.12.7799-7805.2005

Folwell, B. D., McGenity, T. J., and Whitby, C. (2016). Biofilm and planktonic bacterial and fungal communities transforming high-molecular-weight polycyclic aromatic hydrocarbons. Appl. Environ. Microbiol. 82, 2288-2299. doi: 10.1128/AEM.03713-15

Freitas, S., Hatosy, S., Fuhrman, J. A., Huse, S. M., Welch, D. B., Sogin, M. L., et al. (2012). Global distribution and diversity of marine Verrucomicrobia. ISME J. 6, 1499-1505. doi: 10.1038/ismej.2012.3

Frette, L., Jørgensen, N. O. G., Irming, H., and Kroer, N. (2004). Tenacibaculum skagerrakense sp. nov., a marine bacterium isolated from the pelagic zone in Skagerrak, Denmark. Int. J. Syst. Evol. Microbiol. 54, 519-524. doi: 10.1099/ijs.0.02398-0

Fuchsman, C. A., Staley, J. T., Oakley, B. B., Kirkpatrick, J. B., and Murray, J. W. (2012). Free-living and aggregate-associated Planctomycetes in the Black Sea. FEMS Microbiol. Ecol. 80, 402-416. doi: 10.1111/j.1574-6941.2012.01306.x

Gade, D., Gobom, J., and Rabus, R. (2005). Proteomic analysis of carbohydrate catabolism and regulation in the marine bacterium Rhodopirellula baltica. Proteomics 5, 3672-3683. doi: 10.1002/pmic. 200401200

García-Robledo, E., Bohórquez, J., Corzo, A., Jiménez-Arias, J. L., and Papaspyrou, S. (2016). Dynamics of inorganic nutrients in intertidal sediments: porewater, exchangeable and intracellular pools. Front. Microbiol. 7:761. doi: 10.3389/fmicb.2016.00761

García-Robledo, E., Corzo, A., Papaspyrou, S., Jiménez-Arias, J. L., and Villahermosa, D. (2010). Freeze-lysable inorganic nutrients in intertidal sediments: dependence on microphytobenthos abundance. Mar. Ecol. Prog. Ser. 403, 155-163. doi: 10.3354/meps08470

Glöckner, F. O., Kube, M., Bauer, M., Teeling, H., Lombardot, T., Ludwig, W., et al. (2003). Complete genome sequencing of the marine planctomycete Pirellula sp. Strain 1. Proc. Natl. Acad. Sci. U.S.A. 100, 8298-8303. doi: $10.1073 /$ pnas. 1431443100

Goto, N., Mitamura, O., and Terai, H. (2001). Biodegradation of photosynthetically produced extracellular organic carbon from intertidal benthic algae. J. Exp. Mar. Biol. Ecol. 257, 73-86. doi: 10.1016/S0022-0981(00)00329-4

Grasshoff, K., Ehrhardt, M., and KremLing, K. (1983). Methods of Seawater Analysis, 2nd Edn. Weinheim: Verlag Chemie.

Hammer, Ø., Harper, D. A. T., and Ryan, P. D. (2001). Past: paleontological statistics software package for education and data analysis. Palaeontol. Electr. 4:9. Available online at: http://palaeo-electronica.org/2001_1/past/issue1_01. htm

Hanlon, A. R. M., Bellinger, B., Haynes, K., Xiao, G., Hofmann, T. A., Gretz, M. R., et al. (2006). Dynamics of extracellular polymeric substance (EPS) production and loss in an estuarine, diatom-dominated, microalgal biofilm over a tidal emersion-immersion period. Limnol. Oceanogr. 51, 79-93. doi: 10.4319/lo.2006.51.1.0079

Haynes, K., Hofmann, T. A., Smith, C. J., Ball, A. S., Underwood, G. J. C., and Osborn, A. M. (2007). Diatom-derived carbohydrates as factors affecting bacterial community composition in estuarine sediments. Appl. Environ. Microbiol. 73, 6112-6124. doi: 10.1128/AEM.00551-07

Hedges, J. I., and Oades, J. M. (1997). Comparative organic geochemistries of soils and marine sediments. Org. Geochem. 27, 319-361. doi: 10.1016/S0146-6380(97)00056-9

Herlemann, D. P. R., Lundin, D., Labrenz, M., Jürgens, K., Zheng, Z., Aspeborg, H., et al. (2013). Metagenomic de novo assembly of an aquatic representative of the verrucomicrobial class Spartobacteria. mBio 4:e00569-12. doi: 10.1128/mbio.00569-12

Hillebrand, H., and Sommer, U. (1999). The nutrient stoichiometry of benthic microalgal growth: redfield proportions are optimal. Limnol. Oceanogr. 44, 440-446. doi: 10.4319/lo.1999.44.2.0440

Hoagland, K. D., Rosowsky, J. R., Gretz, M. R., and Reomer, S. C. (1993). Diatom extracellular polymeric substances: function, fine structure, chemistry, chemistry and physiology. J. Phycol. 29, 537-556. doi: 10.1111/j.0022-3646.1993.00537.x

Hofmann, T., Hanlon, A. R. M., Taylor, J. D., Ball, A. S., Osborn, A. M., and Underwood, G. J. C. (2009). Dynamics and compositional changes in extracellular carbohydrates in estuarine sediments during degradation. Mar. Ecol. Prog. Ser. 379, 45-58. doi: 10.3354/meps07875

Jung, S.-Y., Oh, T.-K., and Yoon, J.-H. (2006). Tenacibaculum aestuarii sp. nov., isolated from a tidal flat sediment in Korea. Int. J. Syst. Evol. Microbiol. 56, 1577-1581. doi: 10.1099/ijs.0.64302-0

Kristensen, E., and Holmer, M. (2001). Decomposition of plant materials in marine sediment exposed to different electron acceptors $\left(\mathrm{O}_{2}, \mathrm{NO}_{3}^{2-}\right.$, and $\left.\mathrm{SO}_{4}^{2-}\right)$, with 
emphasis on substrate origin, degradation kinetics, and the role of bioturbation. Geochim. Cosmochim. Acta 65, 419-433. doi: 10.1016/S0016-7037(00)00532-9

Lage, O. M., and Bondoso, J. (2011). Planctomycetes diversity associated with macroalgae. FEMS Microbiol. Ecol. 78, 366-375. doi: 10.1111/j.1574-6941.2011.01168.x

Landa, M., Cottrell, M. T., Kirchman, D. L., Kaiser, K., Medeiros, P. M., Tremblay, L., et al. (2014). Phylogenetic and structural response of heterotrophic bacteria to dissolved organic matter of different chemical composition in a continuous culture study. Environ. Microbiol. 16, 1668-1681. doi: $10.1111 / 1462-2920.12242$

Luisetti, T., Turner, R. K., Jickells, T., Andrews, J., Elliott, M., Schaafsma, M., et al. (2014). Coastal Zone Ecosystem Services: from science to values and decision making; a case study. Sci. Total Environ. 493, 682-693. doi: $10.1016 /$ j.scitotenv.2014.05.099

Martinez-Garcia, M., Brazel, D. M., Swan, B. K., Arnosti, C., Chain, P. S., Reitenga, K. G., et al. (2012). Capturing single cell genomes of active polysaccharide degraders: an unexpected contribution of verrucomicrobia. PLoS ONE 7:e35314. doi: 10.1371/journal.pone.0035314

Mayer, L. M. (1995). Sedimentary organic matter preservation: an assessment and speculative synthesis-a comment. Mar. Chem. 49, 123-126. doi: 10.1016/0304-4203(95)00011-F

McKew, B. A., Dumbrell, A. J., Taylor, J. D., McGenity, T. J., and Underwood, G. C. J. (2013). Differences between aerobic and anaerobic degradation of microphytobenthic biofilm-derived organic matter within intertidal sediments. FEMS Microbiol. Ecol. 84, 495-509. doi: 10.1111/1574-6941.12077

McKew, B. A., Taylor, J. D., McGenity, T. J., and Underwood, G. J. C. (2011). Resistance and resilience of benthic biofilm communities from a temperate saltmarsh to desiccation and rewetting. ISME J. 5, 30-41. doi: 10.1038 /ismej.2010.91

Meyer-Reil, L.-A. (1990). Microorganisms in marine sediments: considerations concerning activity measurements. Arch. Hydrobiol. 34, 1-6.

Middelburg, J. J., Barranguet, C., Boschker, H. T. S., Herman, P. M. J., Moens, T., and Heip, C. H. R. (2000). The fate of intertidal microphytobenthos carbon: an in situ ${ }^{13} \mathrm{C}$-labeling study. Limnol. Oceanogr. 45, 1224-1234. doi: $10.4319 /$ lo.2000.45.6.1224

Miki, T., and Jacquet, S. (2010). Indirect interaction in the microbial world: specificities and similarities to plant-insect systems. Popul. Ecol. 52, 475-483. doi: 10.1007/s10144-010-0235-4

Miyatake, T., Moerdijk-Poortvliet, T. C. W., Stal, L. J., and Boschker, H. T. S. (2014). Tracing carbon flow from microphytobenthos to major bacterial groups in an intertidal marine sediment by using an in situ $13 \mathrm{C}$ pulse-chase method. Limnol. Oceanogr. 59, 1275-1287. doi: 10.4319/lo.2014.59.4.1275

Morris, R. M., Longnecker, K., and Giovannoni, S. J. (2006). Pirellula and OM43 are among the dominant lineages identified in an Oregon coast diatom bloom. Environ. Microbiol. 8, 1361-1370. doi: 10.1111/j.1462-2920.2006.01029.x

Muyzer, G., Dewaal, E. C., and Uitterlinden, A. G. (1993). Profiling of complex microbial-populations by denaturing gradient gel-electrophoresis analysis of polymerase chain reaction-amplified genes-coding for 16S rRNA. Appl. Environ. Microbiol. 59, 695-700.

Nedashkovskaya, O. I., Vancanneyt, M., Van Trappen, S., Vandemeulebroecke, K., Lysenko, A. M., Rohde, M., et al. (2004). Description of Algoriphagus aquimarinus sp. nov., Algoriphagus chordae sp. nov. and Algoriphagus winogradskyi sp. nov., from sea water and algae, transfer of Hongiella halophila Yi and Chun 2004 to the genus Algoriphagus as Algoriphagus halophilus comb. nov. and emended descriptions of the genera Algoriphagus Bowman et al. 2003 and Hongiella Yi and Chun 2004. Int. J. Syst. Evol. Microbiol. 54, 1757-1764. doi: 10.1099/ijs.0.02915-0

Oakes, J. M., Eyre, B. D., Middelburg, J. J., and Boschker, H. T. S. (2010). Composition, production, and loss of carbohydrates in subtropical shallow subtidal sandy sediments: rapid processing and long-term retention revealed by 13C-labeling. Limnol. Oceanogr. 55, 2126-2138. doi: 10.4319/lo.2010.55. 5.2126

Orsi, W. D., Smith, J. M., Liu, S., Liu, Z., Sakamoto, C. M., Wilken, S., et al. (2016). Diverse, uncultivated bacteria and archaea underlying the cycling of dissolved protein in the ocean. ISME J. 10, 2158-2173. doi: 10.1038/ismej.2016.20

Parks, D. H., and Beiko, R. G. (2010). Identifying biologically relevant differences between metagenomic communities. Bioinformatics 26, 715-721. doi: 10.1093/bioinformatics/btq041
Parks, D. H., Tyson, G. W., Hugenholtz, P., and Beiko, R. G. (2014). STAMP: statistical analysis of taxonomic and functional profiles. Bioinformatics 30, 3123-3124. doi: 10.1093/bioinformatics/btu494

Passarelli, C., Meziane, T., Thiney, N., Boeuf, D., Jesus, B., Ruivo, M., et al. (2015). Seasonal variations of the composition of microbial biofilms in sandy tidal flats: focus of fatty acids, pigments and exopolymers. Estuar. Coast. Shelf Sci. 153, 29-37. doi: 10.1016/j.ecss.2014.11.013

Perkins, R. G., Underwood, G. J. C., Brotas, V., Snow, G., Jesus, B., and Ribeiro, L. (2001). Responses of microphytobenthos to light: primary production and carbohydrate allocation over an emersion period. Mar. Ecol. Prog. Ser. 223, 101-112. doi: 10.3354/meps223101

Pierre, G., Zhao, J. M., Orvain, F., Dupuy, C., Klein, G., Graber, M., et al. (2014). Seasonal dynamics of extracellular polymeric substances (EPS) in surface sediments of a diatom-dominated intertidal mudflat (MarennesOléron, France). J. Sea Res. 92, 26-35. doi: 10.1016/j.seares.2013.07.018

Steele, D. J., Franklin, D. J., and Underwood, G. J. C. (2014). Protection of cells from salinity stress by extracellular polymeric substances in diatom biofilms. Biofouling 30, 987-998. doi: 10.1080/08927014.2014.960859

Stief, P., Kamp, A., and De Beer, D. (2013). Role of diatoms in the spatial-temporal distribution of intracellular nitrate in intertidal sediments. PLoS ONE 8:e73257. doi: 10.1371/journal.pone.0073257

Suzuki, M., Nakagawa, Y., Harayama, S., and Yamamoto, S. (2001). Phylogenetic analysis and taxonomic study of marine Cytophaga-like bacteria: proposal for Tenacibaculum gen. nov. with Tenacibaculum maritimum comb. nov. and Tenacibaculum ovolyticum comb. nov., and description of Tenacibaculum mesophilum sp. nov. and Tenacibaculum amylolyticum sp. nov. Int. J. Syst. Evol. Microbiol. 51, 1639-1652. doi: 10.1099/00207713-515-1639

Taylor, J. D., McKew, B. A., Kuhl, A., McGenity, T. J., and Underwood, G. J. C. (2013). Microphytobenthic extracellular polymeric substances (EPS) in intertidal sediments fuel both generalist and specialist EPS-degrading bacteria. Limnol. Oceanogr. 58, 1463-1480. doi: 10.4319/lo.2013.58.4.1463

Thingstad, T. F., Våge, S., Storesund, J. E., Sandaa, R-A., and Giske, J. (2014). A theoretical analysis of how strain-specific viruses can control microbial species diversity. Proc. Natl. Acad. Sci. U.S.A. 111, 7813-7818. doi: 10.1073/pnas.1400909111

Thornton, D. C. O., Dong, F., Underwood, G. J. C., and Nedwell, D. B. (2002). Factors affecting microphytobenthic biomass, species composition and production in the Colne estuary (UK). Aquat. Microb. Ecol. 27, 285-300. doi: $10.3354 / \mathrm{ame} 027285$

Thornton, D. C. O., Kopac, S. M., and Long, R. A. (2010). Production and enzymatic hydrolysis of carbohydrates in intertidal sediment. Aquat. Microb. Ecol. 60, 109-125. doi: 10.3354/ame01403

Torti, A., Lever, M. A., and Jørgensen, B. B. (2015). Origin, dynamics, and implications of extracellular DNA pools in maine sediments. Mar. Genomics 24, 185-196. doi: 10.1016/j.margen.2015.08.007

Ubertini, M., Lefebre, S., Rakotomalala, C., and Orvain, F. (2015). Impact of sediment grain-size and biofilm age on Epipelic micrphytobenthos resuspension. J. Exp. Mar. Biol. Ecol. 467, 52-64. doi: 10.1016/j.jembe.2015.02.007

Underwood, G. J. C., Fietz, S., Papadimitriou, S., Thomas, D. N., and Dieckmann, G. S. (2010). Distribution and composition of dissolved extracellular polymeric substances (EPS) in Antarctic sea ice. Mar. Ecol. Prog. Ser. 404, 1-19. doi: 10.3354/meps08557

Underwood, G. J. C., and Paterson, D. M. (2003). The importance of extracellular carbohydrate production by marine epipelic diatoms. Adv. Bot. Res. 40, 183-240. doi: 10.1016/S0065-2296(05)40005-1

Underwood, G. J. C., Paterson, D. M., and Parkes, R. J. (1995). The measurement of microbial carbohydrates exopolymers from intertidal sediments. Limnol. Oceanogr. 40, 1243-1253. doi: 10.4319/lo.1995.40.7.1243

Underwood, G. J. C., Perkins, R. G., Consalvey, M. C., Hanlon, A. R. M., Oxborough, K., Baker, N. R., et al. (2005). Patterns in microphytobenthic primary productivity: species-specific variation in migratory rhythms and photosynthetic efficiency in mixed-species biofilms. Limnol. Oceanogr. 50, 755-767. doi: 10.4319/lo.2005.50.3.0755

Underwood, G. J. C., and Smith, D. J. (1998). Predicting Epipelic diatom exopolymer concentrations in intertidal sediments from sediment chlorophyll a. Microb. Ecol. 35, 116-125. doi: 10.1007/s002489900066 
Våge, S., Storesund, J. E., and Thingstad, T. F. (2013). SAR11 viruses and defensive host strains. Nature 499, E3-E4. doi: 10.1038/nature12387

Wang, Q., Garrity, G. M., Tiedje, J. M., and Cole, J. R. (2007). Naïve Bayesian classifier for rapid assignment of rRNA sequences into the new bacterial taxonomy. Appl. Environ. Microbiol. 73, 5261-5267. doi: 10.1128/AEM.00062-07

Wang, X., Sharp, C. E., Jones, G. M., Grasby, S. E., Brady, A. L., and Dunfield, P. F. (2015). Stable-Isotope-Probing identifies uncultured Planctomycetes as primary degraders of a complex heteropolysaccharide in soil. Appl. Environ. Microbiol. 81, 4607-4615. doi: 10.1128/AEM.00 055-15

Wegner, C. E., Richter-Heitmann, T., Klindworth, A., Klockow, C., Richter, M., Achstetter, T, et al. (2013). Expression of sulfatases genes in Rhodopirellula baltica and the diversity of sulfatases in the genus Rhodopirellula. Mar. Genomics 9, 51-61. doi: 10.1016/j.margen.2012. 12.001

Wustman, B. A., Gretz, M. R., and Hoagland, K. D. (1997). Extracellular matrix assembly in diatoms (Bacilliariophyceae) I. A model of adhesives based on chemical characterization and localization of polysaccharides from the marine diatom Achnanthes longipes and other diatoms. Plant Physiol. 113, 1059-1069. doi: 10.1104/pp.113. 4.1059

Yamaguchi, A., Umezawa, Y., Wada, M., and Sayama, M. (2015). Potential contribution of microalgal intracellular phosphorus to phosphorus distribution in tidal flat sediments during winter. Plankton. Benthos. Res. 10, 1-10. doi: $10.3800 /$ pbr. 10.1
Yilmaz, P., Yarza, P., Rapp, J. Z., and Glöckner, F. O. (2016). Expanding the world of marine bacterial and archaeal clades. Front. Microbiol. 6:1524. doi: 10.3389/fmicb.2015.01524

Yoon, J. H., Kang, S. J., Jung, S. Y., Lee, C. H., and Oh, T. K. (2005). Algoriphagus yeomjeoni sp. nov., isolated from a marine solar saltern of the Yellow Sea, Korea. Int. J. Syst. Evol. Microbiol. 55, 865-870. doi: 10.1099/ijs.0.63479-0

Yoon, J., Matsuo, Y., Adachi, K., Nozawa, M., Matsuda, S., Kasai, H., et al. (2008). Description of Persicirhabdus sediminis gen. nov., sp. nov., Roseibacillus ishigakijimensis gen. nov., sp. nov., Roseibacillus ponti sp. nov., Roseibacillus persicicus sp. nov., Luteolibacter pohnpeiensis gen. nov., sp. nov. and Luteolibacter algae sp. nov., six marine members of the phylum 'Verrucomicrobia', and emended descriptions of the class Verrucomicrobiae, the order Verrucomicrobiales and the family Verrucomicrobiaceae. Int. J. Syst. Evol. Microbiol. 58, 998-1007. doi: 10.1099/ijs.0.65520-0

Conflict of Interest Statement: The authors declare that the research was conducted in the absence of any commercial or financial relationships that could be construed as a potential conflict of interest.

Copyright (C) 2017 Bohórquez, McGenity, Papaspyrou, García-Robledo, Corzo and Underwood. This is an open-access article distributed under the terms of the Creative Commons Attribution License (CC BY). The use, distribution or reproduction in other forums is permitted, provided the original author(s) or licensor are credited and that the original publication in this journal is cited, in accordance with accepted academic practice. No use, distribution or reproduction is permitted which does not comply with these terms. 